Check for updates

Cite this: RSC Adv., 2017, 7, 51233

Received 8th September 2017 Accepted 27th October 2017

DOI: $10.1039 / c 7 r a 10035 c$

rsc.li/rsc-advances

\section{Effects of optical-inert ions on upconversion luminescence and temperature sensing properties of $\mathrm{ScVO}_{4}: 10 \% \mathrm{Yb}^{3+} / 2 \% \mathrm{Er}^{3+}$ nano/micro-particles $\uparrow$}

\author{
Peng Li, ${ }^{a}$ Linna Guo, (D) *a Chenxi Liang, ${ }^{a}$ Tiesheng Li, ${ }^{\text {*a }}$ Penglei Chen, (D) ${ }^{b}$ \\ Minghua Liu (D) ${ }^{* b}$ and Yangjie Wu (D) *a
}

In this paper, $\mathrm{ScVO}_{4}: 10 \% \mathrm{Yb}^{3+} / 2 \% \mathrm{Er}^{3+}$ nano/micro-particles doped with optical-inert metal ions including the alkali metal ions $\left(\mathrm{Li}^{+} / \mathrm{Na}^{+} / \mathrm{K}^{+}\right)$, alkaline-earth metal ions $\left(\mathrm{Mg}^{2+} / \mathrm{Ca}^{2+} / \mathrm{Sr}^{2+} / \mathrm{Ba}^{2+}\right)$ and lanthanide ions $\left(\mathrm{Y}^{3+} / \mathrm{Gd}^{3+} / \mathrm{Lu}^{3+}\right)$ were synthesized by a conventional solid-state method. X-ray diffraction studies show that the prepared $\mathrm{ScVO}_{4}: 10 \% \mathrm{Yb}^{3+} / 2 \% \mathrm{Er}^{3+}$ whether single-doping, codoping or tridoping optical-inert metal ions are highly crystalline in nature with tetragonal phase structure when the doping concentration $\leq 10 \%$. Under a $980 \mathrm{~nm}$ laser diode excitation, the upconversion luminescence was enhanced significantly by single doping of $\mathrm{Li}^{+}, \mathrm{Na}^{+}, \mathrm{K}^{+}, \mathrm{Mg}^{2+}, \mathrm{Ca}^{2+}, \mathrm{Sr}^{2+}, \mathrm{Ba}^{2+}, \mathrm{Y}^{3+}, \mathrm{Gd}^{3+}$ or $\mathrm{Lu}^{3+}$, showing the strongest green emission with $5 \mathrm{~mol} \% \mathrm{Li}^{+}$dopant. For codoping optical-inert metal ions system, it is found that $\mathrm{Li}^{+} / \mathrm{Gd}^{3+}$ couple is the most effective codopant, leading to an drastic increase of the UC luminescence centered at $554 \mathrm{~nm}$ by a factor of 15.3 compared to optical-inert metal ions free sample, while the factor of $\mathrm{Li}^{+} / \mathrm{Ca}^{2+} / \mathrm{Gd}^{3+}$ tridoping system is only 4.6. This work aims to investigate the origin of UC luminescence enhancement for $\mathrm{ScVO}_{4}: 10 \% \mathrm{Yb}^{3+} / 2 \% \mathrm{Er}^{3+}$ after codoping optical-inert ions based on the systematical analyses of the structures, morphologies, chemical states of elements, oxygen defects, optical absorption properties, etc. Furthermore, temperature-sensing performance was also investigated using the fluorescence intensity ratio technique. This opens a new window for studying the cooperation of the optical-inert ions doping effect on improving UC luminescence and temperature sensitivity properties.

\section{Introduction}

Infrared-to-visible upconversion (UC) of rare-earth (RE) iondoped phosphors (UCPs) has been studied extensively in the past few years, due to their huge potential applications in the fields of solid-state lasers, ${ }^{1,2}$ 3D display, ${ }^{3,4}$ fluorescence labeling, ${ }^{5,6}$ bioimaging, ${ }^{7,8}$ therapy ${ }^{9,10}$ and temperature sensor, ${ }^{11-13}$ etc. Despite the renewed interests and rapid progress being made, the UC efficiency of the currently available materials is not high enough for truly wide spread applications. It is therefore imperative to find ways to significantly improve the efficiency. Generally, the UC intensity and quantum efficiency under excitation at $980 \mathrm{~nm}$ is governed by the following three factors: (1) high electronic transition probabilities of the

${ }^{a}$ College of Chemistry and Molecular Engineering, Zhengzhou University, The Key Lab of Chemical Biology and Organic Chemistry of Henan Province, The Key Lab of Nano-information Materials of Zhengzhou, Zhengzhou, 450001, P. R. China. E-mail: guolinna@zzu.edu.cn; lts34@zzu.edu.cn

${ }^{b}$ Beijing National Laboratory for Molecular Science, Institute of Chemistry, Chinese Academy of Sciences, Beijing, 100190, P. R. China

$\dagger$ Electronic supplementary information (ESI) available. See DOI: $10.1039 / \mathrm{c} 7 \mathrm{ra10035c}$ dopants, (2) the energy transfer rate from sensitizer $\left(\mathrm{Yb}^{3+}\right)$ to emission centers $\left(\mathrm{Tm}^{3+}, \mathrm{Er}^{3+}, \mathrm{Ho}^{3+}\right.$ etc. $)$ and (3) the last but the most important, the intensity of $\mathrm{Ln}^{3+}$-doped UC materials strongly depends on intra $4 \mathrm{f}-4 \mathrm{f}$ transition probabilities and is also influenced by the crystal field symmetry and crystallinity of the samples. ${ }^{14}$ In general, there were some strategies that have been employed to achieve high efficiency in UC materials: (1) selection of novel host materials; (2) tailoring local crystal field; (3) plasmonic enhancement; (4) engineering energy transfers; (5) suppression of surface-related deactivations; ${ }^{9}$ and (6) the effective Bragg reflection of photonic crystals. ${ }^{15,16}$ Among them, the more simple and commonly used method is tailoring local crystal field. Therefore, it is possible to modulate UC emissions by tailoring the local crystal field of the luminescent centers in an inorganic host matrix. As is well known that beyond these sensitizer $\left(\mathrm{Yb}^{3+}\right)$ and activators $\left(\mathrm{Tm}^{3+}, \mathrm{Er}^{3+}, \mathrm{Ho}^{3+}\right.$ etc.), the periodic table also provides a rich diversity of optical-inert elements that can be used to modulate emission, or to alter the symmetry around activators, thus influencing UC luminescence (UCL) properties by altering electronic transition probabilities and enhance the UC efficiency. Meanwhile, it is more cheap and economic to enhance UCL intensity through doping the majority of optical-inert ions. By this means, common 
optical-inert ions include alkali metal ions $\left(\mathrm{Li}^{+}, \mathrm{Na}^{+}, \mathrm{K}^{+}\right)$, alkaline-earth metal ions $\left(\mathrm{Ca}^{2+}, \mathrm{Mg}^{2+}, \mathrm{Sr}^{2+}, \mathrm{Ba}^{2+}\right)$, transition metal ions $\left(\mathrm{Mn}^{2+}, \mathrm{Fe}^{3+}\right)$ and some other inactive lanthanide ions $\left(\mathrm{Ln}^{3+}=\mathrm{Gd}^{3+}, \mathrm{Lu}^{3+}\right)$ have been doped into various UCPs to modulate their luminescence properties. ${ }^{17-22}$

For example, Chen et al. ${ }^{23}$ discovered a 10 times increase in blue emissions $\left({ }^{1} \mathrm{D}_{2} \rightarrow{ }^{3} \mathrm{~F}_{4},{ }^{1} \mathrm{G}_{4} \rightarrow{ }^{3} \mathrm{H}_{6}\right)$ in $\mathrm{Gd}_{2} \mathrm{O}_{3}: \mathrm{Yb}^{3+}, \mathrm{Tm}^{3+}$ nanoparticles by doping with $6 \% \mathrm{Li}^{+}$. Song's group ${ }^{24}$ demonstrated 10 and 4 times increases in red $\left({ }^{5} \mathrm{~F}_{4},{ }^{5} \mathrm{~S}_{2} \rightarrow{ }^{5} \mathrm{I}_{8}\right)$ and green $\left({ }^{5} \mathrm{~F}_{5} \rightarrow{ }^{5} \mathrm{I}_{8}\right)$ emissions in $\mathrm{Y}_{2} \mathrm{O}_{3}: 3 \% \mathrm{Li}^{+}, 4 \% \mathrm{Yb}^{3+}, 1 \% \mathrm{Ho}^{3+}$ nanoparticles. Hom et al. ${ }^{25}$ reported that the NIR to NIR UC emission intensity of $10 \mathrm{~mol} \% \mathrm{~K}^{+}$substituted $\mathrm{ZnMoO}_{4}: \mathrm{Tm}^{3+}, \mathrm{Yb}^{3+}$ nanocrystals increased by 21 -fold compared with $\mathrm{K}^{+}$free sample. Our group $^{26}$ found that white UC emission was achieved in the $\mathrm{Lu}_{6} \mathrm{O}_{5} \mathrm{~F}_{8}: 6 \% \mathrm{Yb}^{3+}, 0.3 \% \mathrm{Er}^{3+}, 0.4 \% \mathrm{Tm}^{3+}, 5 \% \mathrm{Li}^{+}$compared to $\mathrm{Li}^{+}$ free sample with the same activator concentration, besides, the integrated UC emission intensity of $\mathrm{Lu}_{6} \mathrm{O}_{5} \mathrm{~F}_{8}: 20 \% \mathrm{Yb}^{3+}, 1 \% \mathrm{Er}^{3+}$, $3 \% \mathrm{Li}^{+}$is 5.5 times as strong as that of commercial UC phosphor $\left(\mathrm{NaYF}_{4}: 20 \% \mathrm{Yb}^{3+}, 2 \% \mathrm{Er}^{3+}\right)$. Aside from alkali metal ions, alkaline-earth metal ions can also be used to tailor the local crystal field. Chen and Wang ${ }^{27}$ explored that UC luminescence intensities of $\mathrm{NaGdF}_{4}: \mathrm{Yb}^{3+} / \mathrm{Er}^{3+}$ were enhanced by about 200 times upon introducing $\mathrm{Ca}^{2+}$ dopants into the phosphors, probably due to a modification of the crystal structure of $\mathrm{NaGdF}_{4}$ and an improvement in the crystallinity. Haase and coworkers ${ }^{28}$ prepared $\mathrm{CaAl}_{12} \mathrm{O}_{19}: \mathrm{Mg}^{2+}, \mathrm{Yb}^{3+}, \mathrm{Er}^{3+}$ UCPs, in which the green and red emissions of the $\mathrm{Er}^{3+}$ ions was improved 4 and 1.5 times, respectively, compared with the counterparts without $\mathrm{Mg}^{2+}$ ions. On the other hand, not only the local site symmetry, but also phase transition may be induced with a higher concentration of host-ion substitution by non-active $\mathrm{Ln}^{3+}$. Liu and co-workers ${ }^{29}$ investigated a $\mathrm{NaYF}_{4}: \mathrm{Er}^{3+}, \mathrm{Yb}^{3+}$ system in which host ion substitution influences the nanocrystal growth process to give simultaneous control over the crystallographic phase, size and optical emission properties of the resulting nanocrystals. It was demonstrated that $\mathrm{NaYF}_{4}$ nanocrystals can be rationally tuned in size (down to ten nanometres), phase (cubic or hexagonal) and UC emission color (green to blue) as well as intensity by replacing $\mathrm{Y}^{3+}$ with $\mathrm{Gd}^{3+}$. Zhang et $a .^{30}$ discovered that the UC enhancement with size decrease has been realized in $\beta-\mathrm{NaLuF}_{4}: \mathrm{Yb}^{3+} / \mathrm{Er}^{3+}$ nanocrystals (NCs) through doping with $\mathrm{Y}^{3+}$ ions. Compared with $\beta$ $\mathrm{NaLu}_{0.78} \mathrm{Yb}_{0.2} \mathrm{Er}_{0.02} \mathrm{~F}_{4}$ and $\beta-\mathrm{NaY}_{0.78} \mathrm{Yb}_{0.2} \mathrm{Er}_{0.02} \mathrm{~F}_{4}$ prepared under the same condition, the green UC emission is enhanced by a factor of 1.8 and 16 , respectively, for $\beta-\mathrm{NaLu}_{0.48} \mathrm{Y}_{0.3} \mathrm{Yb}_{0.2^{-}}$ $\mathrm{Er}_{0.02} \mathrm{~F}_{4}$. UC luminescence of $\mathrm{NaY}_{0.95-x} \mathrm{Yb}_{0.03} \mathrm{Er}_{0.002} \mathrm{Sc}_{x} \mathrm{~F}_{4}$ was enhanced obviously by tridoping $\mathrm{Sc}^{3+}$ ions, contrasted to the untridoped one, especially for higher energy emission. ${ }^{21}$ Comprehensively, it shows a rising trend, indicating that optical-inert ions are becoming a more and more important and hot topic in the field of UCL enhancement. It can be concluded from above reports, most researchers have studied the effect of co-doping with alkali metal ions, alkaline-earth metal ions and inactive $\mathrm{Ln}^{3+}$ ions individually on the structural and UCL properties of phosphors. ${ }^{31-33}$ Comparatively, there is rare research about the effect of combination these optical inert metal ions doping and lack of knowledge on the intercommunication between codopants on the UC luminescence in controlling the properties of UCPs to the best of our knowledge.

In addition, reasons for the UC emission intensity enhancement through optical-inert co-dopants is yet to be determined with complete certainty, and this investigation is still an important and challenging research field. Most reports described the experiment results to the following fact. Some optical inert ions such as $\mathrm{Li}^{+}$may directly act as a flux or sensitizer, and the others could enter into the host lattice, creating oxygen vacancies or altering the crystal field surrounding the activator, then affecting the luminescence performances of the phosphors. ${ }^{34-39}$ It is very important to inquire into the characteristics of codopants so as to further understand the mechanism of enhanced luminescence, and also help us to look for some more effective codoping ions. Such studies would be further helpful to understand the mechanisms involved in enhanced luminescence of optical-inert ions and RE co-doped materials.

In our previous work, ${ }^{40}$ it is demonstrated that $\mathrm{ScVO}_{4}: \mathrm{Yb}^{3+} /$ $\mathrm{Er}^{3+}$ is a green-emitting phosphor with good monochromaticity, while its emission efficiency still needs for the further improvement. So in this work, we focused on the UCL enhancement of $\mathrm{ScVO}_{4}: \mathrm{Yb}^{3+} / \mathrm{Er}^{3+}$ through different kinds of optical-inert ions $\left(\mathrm{Li}^{+} / \mathrm{Na}^{+} / \mathrm{K}^{+}, \mathrm{Mg}^{2+} / \mathrm{Ca}^{2+} / \mathrm{Sr}^{2+} / \mathrm{Ba}^{2+}\right.$ and $\mathrm{Y}^{3+} / \mathrm{Gd}^{3+} /$ $\mathrm{Lu}^{3+}$ ) single doping as well as combination doping. In order for horizontal comparison, the concentrations of $\mathrm{Li}^{+} / \mathrm{Na}^{+} / \mathrm{K}^{+}, \mathrm{Mg}^{2+} /$ $\mathrm{Ca}^{2+} / \mathrm{Sr}^{2+} / \mathrm{Ba}^{2+}$ and $\mathrm{Y}^{3+} / \mathrm{Gd}^{3+} / \mathrm{Lu}^{3+}$ are chosen to be with the same value, respectively. Meanwhile, combination these optical inert metal ions is a wishful and challengeable task since their radius and valance are different. Overall, the present work provides a comparative study including some powerful evidences and a deep understanding on the origin of UCL enhancement for the $\mathrm{ScVO}_{4}: \mathrm{Yb}^{3+} / \mathrm{Er}^{3+}$ phosphors after optical-inert ions doping in either way.

On the other hand, during the operation of electronic and photonic devices, temperature is needed to be monitored for the best performance. Therefore, accurate sensing and mapping of temperature in a non-invasive way is a challenging field of research. ${ }^{\mathbf{4 1 - 4 4}}$ Hence, this research-need motivated us to tailor the structural and UCL properties of $\mathrm{ScVO}_{4}: \mathrm{Yb}^{3+} / \mathrm{Er}^{3+}$ nano/ microcrystals with optical-inert ions incorporation and to study the temperature sensing performance. Based on the above points, in this work, we employed a modified molten salt method to prepare $\mathrm{Yb}^{3+} / \mathrm{Er}^{3+}$-codoped $\mathrm{ScVO}_{4}$ UCPs, adjusting UC luminescence and temperature-sensing performance by codoping optical-inert ions $\left(\mathrm{Li}^{+} / \mathrm{Na}^{+} / \mathrm{K}^{+}, \mathrm{Mg}^{2+} / \mathrm{Ca}^{2+} / \mathrm{Sr}^{2+} / \mathrm{Ba}^{2+}\right.$ and $\left.\mathrm{Y}^{3+} / \mathrm{Gd}^{3+} / \mathrm{Lu}^{3+}\right)$, to achieve the purpose of kill two birds with one stone.

Comprehensively, it shows a rising trend, indicating that optical-inert ions are becoming a more and more important and hot topic in the field of UCL enhancement. It can be concluded from above reports, most researchers have studied the effect of co-doping with alkali metal ions, alkaline-earth metal ions and inactive $\mathrm{Ln}^{3+}$ ions individually on the structural and UCL properties of phosphors. Comparatively, there is rare research about the effect of combination these optical inert metal ions 
doping and lack of knowledge on the intercommunication between codopants on the UC luminescence in controlling the properties of UCPs to the best of our knowledge.

\section{Experimental}

\subsection{Synthesis}

The raw materials $\mathrm{Sc}_{2} \mathrm{O}_{3}$ (99.99\%), $\mathrm{Yb}_{2} \mathrm{O}_{3}$ (99.99\%), $\mathrm{Er}_{2} \mathrm{O}_{3}$ (99.99\%), and $\mathrm{NH}_{4} \mathrm{VO}_{3}$ (A. R.) were used directly without any further purification. The stoichiometric raw materials were ground in an agate mortar and heated to $800{ }^{\circ} \mathrm{C}$ for $4 \mathrm{~h}$ in air. Then the as-synthesized samples were slowly cooled to room temperature.

\subsection{Characterization}

The phase purity was determined using a Rigaku D/MAX-2400 powder X-ray diffractometer (XRD) with $\mathrm{Cu} \mathrm{K} \alpha$ radiation $(\lambda=$ $1.54178 \AA$ ) operating at $40 \mathrm{kV}$ and $60 \mathrm{~mA}$. The size, shape and structure of the as-prepared samples were characterized by SEM (S-4800). The room temperature Raman spectra were measured at a backscattering geometry using an Ar-ion laser (Coherent Innova 70) operating at $488 \mathrm{~nm}$ as the excitation source. Spectra were recorded by a double grating spectrometer (Spex 1403) equipped with standard photon counting equipment. XPS In the measurements of UC emission spectra, a continuous $980 \mathrm{~nm}$ laser diode (LD) with maximum power of $1.0 \mathrm{~W}$ was used as an excitation source, and the emission was collected using a HORIBA JOBIN YVON Fluorolog-3 spectrofluorometer system. The chemical components were analyzed by Fourier transform infrared spectroscopy (FT-IR, Nicolet NEXUS 670). All the spectral measurements were performed at room temperature.

\section{Results and discussion}

3.1 Effects of optical-inert ions on phase and morphology of $\mathrm{ScVO}_{4}: 10 \% \mathrm{Yb}^{3+} / 2 \% \mathrm{Er}^{3+}$

Fig. 1a shows the XRD patterns of optically inert ions $\left(\mathrm{Li}^{+}, \mathrm{Ca}^{2+}\right.$, $\mathrm{Gd}^{3+}$ ) single-doped, co-doped or tri-doped $\mathrm{ScVO}_{4}: 10 \% \mathrm{Yb}^{3+} / 2 \%$ $\mathrm{Er}^{3+}$ phosphors. The diffraction peaks of $\mathrm{ScVO}_{4}: \mathrm{Yb}^{3+} / \mathrm{Er}^{3+}$ (optically inert ions free) can be well indexed, following a pure zircon-type structure. The main diffraction peaks shift toward
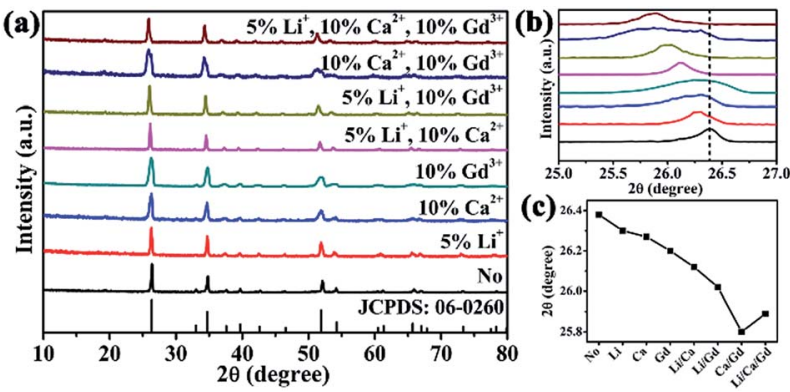

Fig. 1 (a) XRD patterns, (b) shifting of main diffraction peaks, (c) changes in main diffraction peaks position of $\mathrm{Li}^{+}, \mathrm{Ca}^{2+}, \mathrm{Gd}^{3+}$ doped $\mathrm{ScVO}_{4}: 10 \% \mathrm{Yb}^{3+} / 2 \% \mathrm{Er}^{3+}$ ("No" represents $\mathrm{ScVO}_{4}: 10 \% \mathrm{Yb}^{3+} / 2 \% \mathrm{Er}^{3+}$ ). smaller angles corresponding to the standard pattern of $\mathrm{ScVO}_{4}$ (JCPDS No. 06-0260) referenced below, indicating that the substitution of $\mathrm{Sc}^{3+}$ ions by $\mathrm{Yb}^{3+} / \mathrm{Er}^{3+}$ ions cause the host lattice to expand because the ionic radii of $\mathrm{Yb}^{3+}(0.86 \AA), \mathrm{Er}^{3+}(0.88 \AA)$ is larger than that of $\mathrm{Sc}^{3+}(0.75 \AA)$. Besides, it was noticed that the samples were still well crystalline and no other impurity phase was generated upon optically inert ions doping. To further evaluate the effect of optically inert ions on crystal structure, the main diffraction peaks (220) are compared for $\mathrm{ScVO}_{4}: 10 \% \mathrm{Yb}^{3+}$ / $2 \% \mathrm{Er}^{3+}$ with different kinds of optically inert ions doped or not, as show in Fig. $1 b$ and c. Although the main diffraction peak moves irregular with doping one, two or three kinds of optically inert ions, it is clear that the peak shift towards smaller angles on the whole. In the tetragonal $\mathrm{ScVO}_{4}$ host lattice, the optically inert ions $\left(\mathrm{Li}^{+}, \mathrm{Ca}^{2+}\right.$ or $\left.\mathrm{Gd}^{3+}\right)$ can enter $\mathrm{ScVO}_{4}$ crystal site through substituting for the $\mathrm{Sc}^{3+}$ ions or interstitial sites or coexist in the two ways. Especially, it is more complicated that two or three optically inert ions co-doped into the system of $\mathrm{ScVO}_{4}: \mathrm{Yb} / \mathrm{Er}$. According to the Bragg's law $2 d \sin \theta=n \lambda$, where $d$ is the interplanar distance, $\theta$ is the diffraction angle, and $\lambda$ is the diffraction wavelength. Regardless optically inert ions $\left(\mathrm{Li}^{+}(0.76 \AA)\right.$, $\mathrm{Ca}^{2+}(1.00 \AA)$ or $\left.\mathrm{Gd}^{3+}(0.94 \AA)\right)$ with larger radius substituted the $\mathrm{Sc}^{3+}(0.75 \AA)$ or occupy the interstitial sites, the interplanar distance increased, resulting in the (220) position shifting toward the lower $2 \theta$ angle. Our experimental result is in accordance with this theoretical analysis, while different optical inert ions doping or doping method would cause the XRD peak of (220) to produce different degrees of shift to the left.

\subsection{SEM studies}

The surface morphology and crystallinity of solid host materials are important parameters which determine the emission characteristics of phosphors. The microstructural analysis of $\mathrm{ScVO}_{4}: 10 \% \mathrm{Yb}^{3+} / 2 \% \mathrm{Er}^{3+}$ and optically inert ions doped $\mathrm{ScVO}_{4}: 10 \% \mathrm{Yb}^{3+} / 2 \% \mathrm{Er}^{3+}$ samples was performed with the help of SEM examination (Fig. 2). From Fig. 2, it is clear from the SEM image that particles with the variation sizes are not uniformly distributed throughout the surface, which is mainly caused by the inhomogeneous distribution of temperature during synthesis of the material by the solid-state technique. On the whole, the synthesized particles without optically inert ions doping appear chips-like shape, whereas cobblestone-like shape and agglomerated irregular polyhedron morphology particles were obtained when $\mathrm{Ca}^{2+}$ or $\mathrm{Li}^{+}$ions were doped, while chips-like shape was basically remained when $\mathrm{Gd}^{3+}$ doped. From the local point of view, Fig. 2a shows that agglomeration chips-like nanoparticles with diameter of about 140-400 nm and length of about $750-1770 \mathrm{~nm}$ were obtained in the $\mathrm{ScVO}_{4}: 10 \% \mathrm{Yb}^{3+} / 2 \% \mathrm{Er}^{3+}$. As shown in Fig. $2 \mathrm{~b}$, when $\mathrm{Gd}^{3+}$ was further doped into the $\mathrm{ScVO}_{4}: 10 \% \mathrm{Yb}^{3+} / 2 \% \mathrm{Er}^{3+}$ sample, the morphology did not change greatly, remained the chips-like shape except the size were enlarged of diameter ranging from $344 \mathrm{~nm}$ to $707 \mathrm{~nm}$ and length $1134-1879 \mathrm{~nm}$, due to the radius of $\mathrm{Gd}^{3+}$ is similar with that of $\mathrm{Sc}^{3+}$. In sharp contrast, when the smallest metal ions $\mathrm{Li}^{+}$doped into the lattice, the SEM image (Fig. 2c) display an irregular stone-like with corner angle 

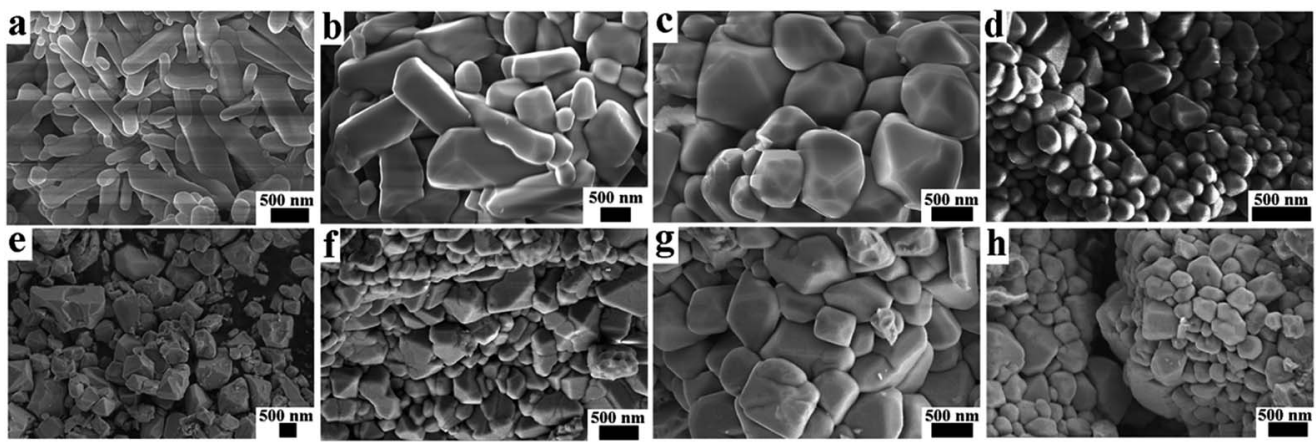

Fig. 2 SEM of (a) optically-inert ions free,

(b) $\mathrm{Gd}^{3+}$

(c) $\mathrm{Li}^{+}$,

(d) $\mathrm{Ca}^{2+}$

(e) $\mathrm{Li}^{+} / \mathrm{Gd}^{3+}$, (f) $\mathrm{Ca}^{2+} / \mathrm{Gd}^{3+}$

(g) $\mathrm{Li}^{+} / \mathrm{Ca}^{2+}$

(h) $\mathrm{Li}^{+} / \mathrm{Ca}^{2+} / \mathrm{Gd}^{3+}$ co-doped $\mathrm{ScVO}_{4}: 10 \% \mathrm{Yb}^{3+} / 2 \% \mathrm{Er}^{3+}$

appearance, and the surface just looks completely smooth and integrated. If $\mathrm{Ca}^{2+}$ was introduced into the $\mathrm{ScVO}_{4}: 10 \% \mathrm{Yb}^{3+} / 2 \%$ $\mathrm{Er}^{3+}$ system, the resulting nanoparticles appear nearly smooth and much more uniform cobblestone in shape. Whereas, as shown in Fig. 2e-g, if doping combination two kinds of $\mathrm{Li}^{+}, \mathrm{Ca}^{2+}$ or $\mathrm{Gd}^{3+}$ into $\mathrm{ScVO}_{4}: 10 \% \mathrm{Yb}^{3+} / 2 \% \mathrm{Er}^{3+}$, it is worth noting that the surface just looks coarse and imperfect, and the size are not uniform, ranging from 200-1000 nm. Especially for $\mathrm{Li}^{+} / \mathrm{Ca}^{2+}$, $\mathrm{Gd}^{3+}$ tri-doped into $\mathrm{ScVO}_{4}: 10 \% \mathrm{Yb}^{3+} / 2 \% \mathrm{Er}^{3+}$, as displayed in Fig. $2 \mathrm{~h}$, both diameter and length decreased more quickly, resulting in small agglomerated nanoparticles with size of 200$500 \mathrm{~nm}$. These results obviously indicate that the optically-inert ions doping indeed alters the particle growth process. To express the changeable morphology and size with different optical-inert ions clearly, the detailed size and shape of all these samples were listed in Table 1.

\subsection{UC photoluminescence properties}

3.3.1 Comparison of UC luminescence of different concentrations of alkali metal ions single doped $\mathrm{ScVO}_{4}: 10 \%$ $\mathbf{Y b}^{3+} / 2 \% \mathbf{E r}^{3+}$. Since the optical properties of UCPs are determined predominantly by the combination and concentrations of the dopants, the $10 \% \mathrm{Yb}^{3+} / 2 \% \mathrm{Er}^{3+}$-doped $\mathrm{ScVO}_{4}$ sample was chosen to test the effect of $\mathrm{Li}^{+}$doping which is the smallest alkali metal ion, because the $10 \% \mathrm{Yb}^{3+} / 2 \% \mathrm{Er}^{3+}$ doping in this material showed the best results (see reference). The XRD

Table 1 Summary of the corresponding morphologies and dimensions of samples with different optically-inert ions

\begin{tabular}{lll}
\hline Optically-inert ions & Morphology & Size $(\mathrm{nm})$ \\
\hline $\mathrm{No}$ & Chips-like & $\begin{array}{l}\text { Length: } 750-1770 ; \\
\text { diameter: } 140-440\end{array}$ \\
& Smooth stone & $971-1208$ \\
$\mathrm{Li}^{+}$ & Cobblestone & $176-317$ \\
$\mathrm{Ca}^{2+}$ & Chips-like & Length: $1134-1879 ;$ \\
$\mathrm{Gd}^{3+}$ & & diameter: $344-707$ \\
& Smooth stone & $400-800$ \\
$\mathrm{Li}^{+} / \mathrm{Ca}^{2+}$ & Stone fragments & $400-1400$ \\
$\mathrm{Li}^{+} / \mathrm{Gd}^{3+}$ & Smooth stone & $200-600$ \\
$\mathrm{Ca}^{2+} / \mathrm{Gd}^{3+}$ & Rough stone & $200-500$ \\
$\mathrm{Li}^{+} / \mathrm{Ca}^{2+} / \mathrm{Gd}^{3+}$ & &
\end{tabular}

patterns of $\mathrm{ScVO}_{4}: 10 \% \mathrm{Yb}^{3+} / 2 \% \mathrm{Er}^{3+}$ phosphors doped with $0-$ $10 \mathrm{~mol} \%$ of $\mathrm{Li}^{+}$are shown in Fig. 3a. All the diffraction peaks can be well indexed to the tetragonal phase $\mathrm{ScVO}_{4}$ (JCPDS No. 06-0260). All samples were well crystalline and no other impurity phase appeared with increasing $\mathrm{Li}^{+}$doping concentration even reach $10 \mathrm{~mol} \%$. Under excitation of a $980 \mathrm{~nm}$ diode laser, the UC emission spectra of $\mathrm{ScVO}_{4}: 10 \% \mathrm{Yb}^{3+} / 2 \% \mathrm{Er}^{3+}$ phosphors doped with 1, 3, 5, 7 and $10 \mathrm{~mol} \% \mathrm{Li}^{+}$ions, have been measured, as displayed in Fig. 3b. Two strong primary bands at about 522 and $554 \mathrm{~nm}$ are assigned to the ${ }^{2} \mathrm{H}_{11 / 2} \rightarrow{ }^{4} \mathrm{I}_{15 / 2}$ and ${ }^{4} \mathrm{~S}_{3 / 2} \rightarrow{ }^{4} \mathrm{I}_{15 / 2}$ transitions of the $\mathrm{Er}^{3+}$ ions, respectively. A weak band at about $671 \mathrm{~nm}$ is ascribed to the ${ }^{4} \mathrm{~F}_{9 / 2} \rightarrow{ }^{4} \mathrm{I}_{15 / 2}$ transition of $\mathrm{Er}^{3+}$ ions. The intensities of both green and red emissions improved with the increase of $\mathrm{Li}^{+}$doping concentration from 0 to $5 \mathrm{~mol} \%$, and subsequently decreased with further increase of $\mathrm{Li}^{+}$concentration from 5 to $10 \mathrm{~mol} \%$. Especially, much higher concentration of $\mathrm{Li}^{+}$dopant, such as $10 \%$, can further improve the UC emission of $\mathrm{Er}^{3+}$ but relatively slightly. Moreover, the emission intensity of the strongest sample is about 6.1 times as high as that of the $\mathrm{Li}^{+}$free sample.

As well as $\mathrm{Li}^{+}$, other alkali metal ions like $\mathrm{Na}^{+}$or $\mathrm{K}^{+}$might possibly influence the final crystal structure and UC luminescence, so $\mathrm{Li}^{+}, \mathrm{Na}^{+}$or $\mathrm{K}^{+}$with the same doping concentration $5 \mathrm{~mol} \%$ were studied and compared in a similar way. The XRD patterns of different alkali metal ions doped $\mathrm{ScVO}_{4}: 10 \% \mathrm{Yb}^{3+} /$ $2 \% \mathrm{Er}^{3+}$ are presented in supporting Fig. S1a. $\dagger$ All of the XRD patterns could clearly be indexed to the pure tetragonal phase of $\mathrm{ScVO}_{4}$ (JCPDS No. 06-0260), and no trace of other phases or impurities were observed, indicating all the optical-inert ions and $\mathrm{Yb}^{3+} / \mathrm{Er}^{3+}$ ions are incorporated into the $\mathrm{ScVO}_{4}$ host matrix and formed a solid solution structure. The UC luminescent performance of alkali metal ions doping $\mathrm{ScVO}_{4}: 10 \% \mathrm{Yb}^{3+} / 2 \%$ $\mathrm{Er}^{3+}$ was studied, as exhibited in Fig. S1b.† Obviously, addition of alkali metal ions significantly intensified the UC emission intensities of all the two emission bands and the trend of increment is the same for the two emission bands as: $\mathrm{Li}^{+}>\mathrm{Na}^{+}>$ $\mathrm{K}^{+}>$No alkali metal ions. It is also observed that all the UC bands are splitted into several Stark components. The UC luminescence splitting from ${ }^{4} \mathrm{~S}_{3 / 2} \rightarrow{ }^{4} \mathrm{I}_{15 / 2}$ and ${ }^{2} \mathrm{H}_{11 / 2} \rightarrow{ }^{4} \mathrm{I}_{15 / 2}$ transitions of $\mathrm{Er}^{3+}$ was observed results from the coordination field effect of host matrices. Similar phenomenon were also observed in previous reports. ${ }^{45}$ 

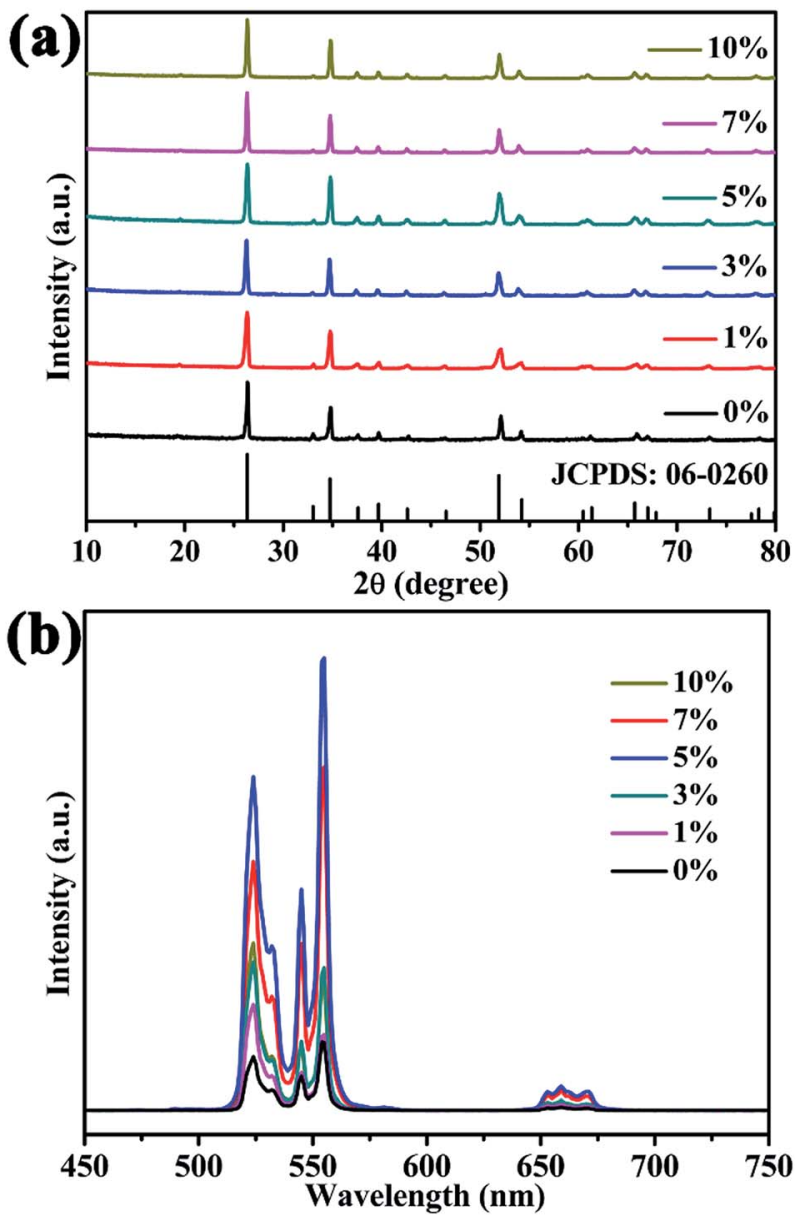

Fig. 3 XRD patterns (a), UC emission spectra (b) of $\mathrm{Li}^{+}(1-10 \mathrm{~mol} \%)$ doped $\mathrm{ScVO}_{4}: 10 \% \mathrm{Yb}^{3+} / 2 \% \mathrm{Er}^{3+}$ samples.

3.3.2 Comparison of UC luminescence of different concentrations of alkaline earth metal ions single doped $\mathrm{ScVO}_{\mathbf{4}}: \mathbf{1 0} \% \mathrm{Yb}^{3+} / \mathbf{2} \% \mathrm{Er}^{3+}$. Similarly with 3.3 .1 , in order to determine the optimal doping concentrations, UC luminescence intensity of $\mathrm{ScVO}_{4}: 10 \% \mathrm{Yb}^{3+} / 2 \% \mathrm{Er}^{3+}$ doped with different concentrations of $\mathrm{Ca}^{2+}$ from $1 \mathrm{~mol} \%$ to $10 \mathrm{~mol} \%$ was investigated. The XRD patterns of the as-prepared $\mathrm{ScVO}_{4}: 10 \% \mathrm{Yb}^{3+} / 2 \%$ $\mathrm{Er}^{3+} / x \% \mathrm{Ca}^{2+}(x=0-10)$ are shown in Fig. $4 \mathrm{a}$, according with that of JCPDS No. 06-0260, indicating that these samples are of single phase. Under $980 \mathrm{~nm}$ laser excitation, all the $\mathrm{ScVO}_{4}: 10 \%$ $\mathrm{Yb}^{3+} / 2 \% \mathrm{Er}^{3+} / x \% \mathrm{Ca}^{2+}(x=0-10)$ samples emit green light, as shown in Fig. 4b. The emission bands at 522, 554 and $671 \mathrm{~nm}$ are ascribed to the transitions of ${ }^{2} \mathrm{H}_{11 / 2} \rightarrow{ }^{4} \mathrm{I}_{15 / 2},{ }^{4} \mathrm{~S}_{3 / 2} \rightarrow{ }^{4} \mathrm{I}_{15 / 2}$ and ${ }^{4} \mathrm{~F}_{9 / 2} \rightarrow{ }^{4} \mathrm{I}_{15 / 2}$, respectively. Their emission intensity is affected by the $\mathrm{Ca}^{2+}$ concentrations. At the optimal $\mathrm{Ca}^{2+}$ concentration of $1 \mathrm{~mol} \%$, the emission intensity at $554 \mathrm{~nm}$ increases 3.7 times.

Similarly, other alkaline earth metal ions $\left(\mathrm{Mg}^{2+}, \mathrm{Sr}^{2+}\right.$ or $\left.\mathrm{Ba}^{2+}\right)$ with doping concentration $1 \mathrm{~mol} \%$ were also studied to investigate their influence on the final crystal structure and UCL properties. Fig. S2a $\dagger$ depicts XRD patterns of the $\mathrm{ScVO}_{4}: 10 \%$ $\mathrm{Yb}^{3+} / 2 \% \mathrm{Er}^{3+}$ doped with alkaline earth metal ions $\left(\mathrm{Mg}^{2+}, \mathrm{Sr}^{2+}\right.$ or $\left.\mathrm{Ba}^{2+}\right)$, all the diffraction peaks of samples still correspond to the
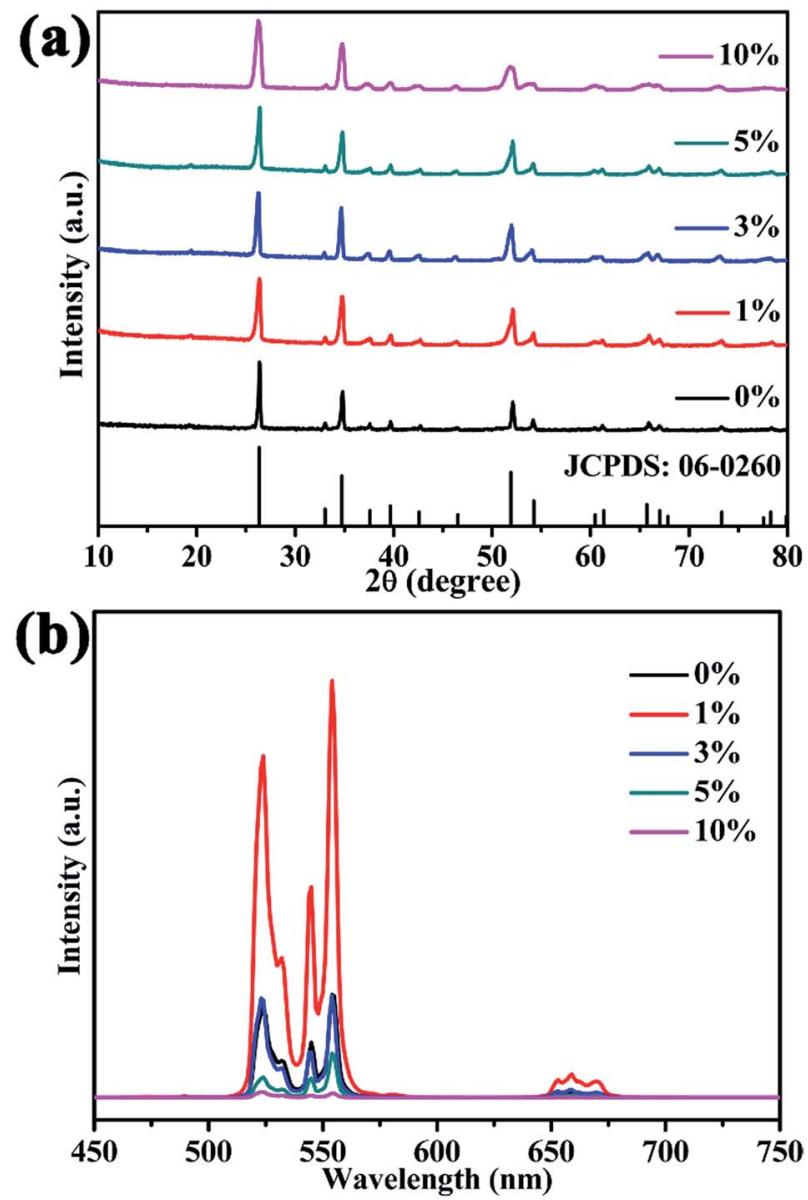

Fig. 4 XRD patterns (a), UC emission spectra (b) of $\mathrm{Ca}^{2+}$ (1-10 mol\%) doped $\mathrm{ScVO}_{4}: 10 \% \mathrm{Yb}^{3+} / 2 \% \mathrm{Er}^{3+}$ samples.

tetragonal structure (JCPDS No. 06-0260) and no other impurity phase was detected. The normalized UC emission spectra of calcined $\mathrm{ScVO}_{4}: 10 \% \mathrm{Yb}^{3+} / 2 \% \mathrm{Er}^{3+}$ doped with alkaline earth metal ions $\left(\mathrm{Mg}^{2+}, \mathrm{Ca}^{2+}, \mathrm{Sr}^{2+}\right.$ or $\left.\mathrm{Ba}^{2+}\right)$ are shown in Fig. S2b. $\dagger$ Obviously, addition of alkaline earth metal ions enhanced the UC emission intensities and the trend of increment is as: $\mathrm{Sr}^{2+}>$ $\mathrm{Ca}^{2+}>\mathrm{Mg}^{2+}>\mathrm{Ba}^{2+}>\mathrm{No}$ alkaline earth metal ions. Doping with alkaline earth metal ions $\left(\mathrm{Mg}^{2+}, \mathrm{Ca}^{2+}, \mathrm{Sr}^{2+}\right.$ or $\left.\mathrm{Ba}^{2+}\right)$ intensified the UC emission by almost 2.5, 3.7, 4.7 and 2.3 fold to that of optically inert ions-absent sample, respectively.

3.3.3 Comparison of UC luminescence of different concentrations of inactive $\mathrm{Ln}^{3+}$ single doped $\mathrm{ScVO}_{4}: 10 \% \mathrm{Yb}^{3+} /$ $\mathbf{2 \%} \mathbf{E r}^{3+}$. Considering the $\mathrm{Gd}^{3+}$ ion has similar properties with $\mathrm{Sc}^{3+}$, a large range of $0-100 \mathrm{~mol} \% \mathrm{Gd}^{3+}$ ions were single-doped into the $\mathrm{ScVO}_{4}: 10 \% \mathrm{Yb}^{3+} / 2 \% \mathrm{Er}^{3+}$ sample. The XRD patterns of $\mathrm{ScVO}_{4}: 10 \% \mathrm{Yb}^{3+} / 2 \% \mathrm{Er}^{3+} / x \% \mathrm{Gd}^{3+}(0 \leq x \leq 100)$ are shown in Fig. 5a. Compared with the standard patterns of $\mathrm{ScVO}_{4}$ and $\mathrm{GdVO}_{4}$, when the $\mathrm{Gd}^{3+}$ content is less than or equal to $10 \mathrm{~mol} \%$, diffraction peaks of the obtained sample can be well indexed as pure $\mathrm{ScVO}_{4}$ phase. On doping with increased $\mathrm{Gd}^{3+}$ concentrations to $30 \mathrm{~mol} \%, \mathrm{GdVO}_{4}$ phase started to appear, and the sample composed of two phases, ScVO4: tetragonal phase, and GdVO4: tetragonal phase. When the $\mathrm{Gd}^{3+}$ content reaches up to 

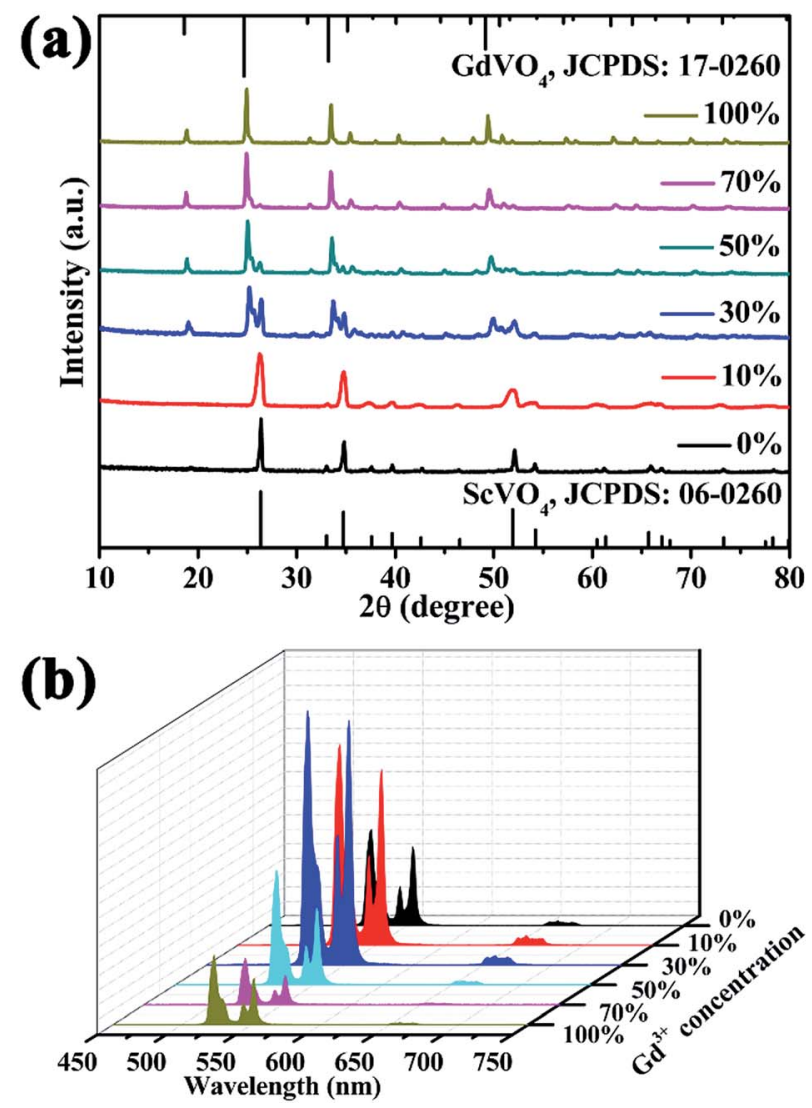

Fig. 5 XRD patterns (a) and UC emission spectra (b) of $0-100 \% \mathrm{Gd}^{3+}$ doped $\mathrm{ScVO}_{4}: 10 \% \mathrm{Yb}^{3+} / 2 \% \mathrm{Er}^{3+}$.

$50 \mathrm{~mol} \%$, the peaks of $\mathrm{ScVO}_{4}$ phase fall sharply, and $\mathrm{GdVO}_{4}$ phase dominate on a large scale. When the $\mathrm{Gd}^{3+}$ content further increases to $70 \mathrm{~mol} \%, \mathrm{ScVO}_{4}$ phase nearly disappears and almost pure $\mathrm{GdVO}_{4}$ phase can be achieved. Finally, the pure tetragonal phase of $\mathrm{GdVO}_{4}$ was obtained as the $\mathrm{Gd}^{3+}$ ion concentration reached up to $100 \mathrm{~mol} \%$. In a word, the gradually decrease of diffraction peak intensities of the $\mathrm{ScVO}_{4}$-phase is correlated with an increasing $\mathrm{Gd}^{3+}$ dopant concentration and the rise of the diffraction peak intensity of the $\mathrm{GdVO}_{4}$ phase.

In order to reveal the concentration-dependent UCL properties and obtain the optimum concentration of $\mathrm{Gd}^{3+}$ ions doping in host lattice, the $\mathrm{Gd}^{3+}$ concentration dependent UCL spectra of the $\mathrm{ScVO}_{4}: 10 \% \mathrm{Yb}^{3+} / 2 \% \mathrm{Er}^{3+}$ samples are shown in Fig. $5 \mathrm{~b}$. As can be evidently seen that the doping of $\mathrm{Gd}^{3+}$ ion (even $\mathrm{Gd}^{3+}$ ion concentration reached $100 \mathrm{~mol} \%$ ) cannot change the position of typical emission of $\mathrm{Er}^{3+}$. The UC emission intensity enhanced with rising $\mathrm{Gd}^{3+}$ doping content from 0 to $30 \mathrm{~mol} \%$, and then started to weaken when the $\mathrm{Gd}^{3+}$ concentration exceeds $30 \mathrm{~mol} \%$. The UC emission intensities at $554 \mathrm{~nm}$ in $\mathrm{ScVO}_{4}: 10 \% \mathrm{Yb}^{3+} / 2 \% \mathrm{Er}^{3+}$ nanocrystals doped with $30 \mathrm{~mol} \% \mathrm{Gd}^{3+}$ are about 3.2 times than that of $\mathrm{Gd}^{3+}$-absent sample. The red emission intensity has a little change after $\mathrm{Gd}^{3+}$ introducing. In stark contrast, the UC luminescence intensity of $\mathrm{GdVO}_{4}: 10 \% \mathrm{Yb}^{3+} / 2 \% \mathrm{Er}^{3+}\left(\mathrm{Gd}^{3+}\right.$ content reaches up to $100 \mathrm{~mol} \%$ ) is 1.2 times lower than that of $\mathrm{ScVO}_{4}: 10 \% \mathrm{Yb}^{3+} / 2 \% \mathrm{Er}^{3+}\left(\mathrm{Gd}^{3+}\right.$ concentration $\left.0 \mathrm{~mol} \%\right)$, indicating that $\mathrm{ScVO}_{4}$ is more suitable as UCL host than $\mathrm{GdVO}_{4}$.
From the analysis above, when the $\mathrm{Gd}^{3+}$ content is less than or equal to $10 \mathrm{~mol} \%$, all the X-ray diffraction peaks of the sample can be well indexed as pure $\mathrm{ScVO}_{4}$ phase. Therefore, the $10 \mathrm{~mol} \%$ doping content of $\mathrm{Y}^{3+}, \mathrm{Lu}^{3+}$ was chosen for the following investigations. Firstly, XRD patterns of these samples are shown in Fig. S3. $\dagger$ All the diffraction peaks can be indexed to those of the tetragonal phase $\mathrm{ScVO}_{4}$ (JCPDS card No. 06-0260). Influences of non-luminescent $\mathrm{Y}^{3+}, \mathrm{Gd}^{3+}$ or $\mathrm{Lu}^{3+}$ dopant on the UCL properties of $\mathrm{ScVO}_{4}: 10 \% \mathrm{Yb}^{3+} / 2 \% \mathrm{Er}^{3+}$ phosphors were compared and studied, as shown in Fig. S3b. $\dagger$ Obviously, addition of $\mathrm{Y}^{3+} / \mathrm{Gd}^{3+} / \mathrm{Lu}^{3+}$ significantly intensified the UC emission at the green as well as red region and the order of increment was $\mathrm{Lu}^{3+}>\mathrm{Gd}^{3+}>\mathrm{Y}^{3+}>$ inactive ions free. It is worthwhile pointing out that substitution of $10 \mathrm{~mol} \% \mathrm{Lu}^{3+}$ intensified the UC emission by almost 3.4 fold than that of nonactive RE ions free-sample.

Fig. 6 summaries the UCL intensity of $\mathrm{ScVO}_{4}: 10 \% \mathrm{Yb}^{3+} / 2 \%$ $\mathrm{Er}^{3+}$ with various optical-inert ions single substitution. It can be seen clearly that optical-inert ions doping enhanced the UCL intensity in different degree. Among them, $5 \mathrm{~mol} \% \mathrm{Li}^{+}$doping shows the biggest enhancement, by almost 6.1-fold compared to that of $\mathrm{ScVO}_{4}: 10 \% \mathrm{Yb}^{3+} / 2 \% \mathrm{Er}^{3+}$

3.3.4 Comparison of UC luminescence of different concentrations of $\mathrm{Li}^{+}, \mathrm{Ca}^{2+}, \mathrm{Gd}^{3+}$ co- or tri-doped $\mathrm{ScVO}_{4}: 10 \%$ $\mathbf{Y b}^{3+} / 2 \% \mathbf{E r}^{3+}$. From the Section of 3.3.1, 3.3.2 and 3.3.3, it is found that UC luminescence could be enhanced through single doping $\mathrm{Li}^{+}, \mathrm{Ca}^{2+}$ or $\mathrm{Gd}^{3+}$, respectively. In this section, in order to accurately compare the UCL intensity and reveal synergistic effect of $\mathrm{Li}^{+} / \mathrm{Ca}^{2+} / \mathrm{Gd}^{3+}$, the UCL properties was investigated for the three optimal samples under the same condition. Fig. 7 shows the UC emission spectra of a series of $\mathrm{Li}^{+}, \mathrm{Ca}^{2+}, \mathrm{Gd}^{3+}$ with optimal concentration co- or tri-doped $\mathrm{ScVO}_{4}: 10 \% \mathrm{Yb}^{3+} / 2 \% \mathrm{Er}^{3+}$.

No matter in which kind of doping way, the UC emission peak positions remain unaltered, while the UCL intensity varied differently. Among these samples, the $\mathrm{Li}^{+} / \mathrm{Gd}^{3+}$ codoped $\mathrm{ScVO}_{4}: 10 \% \mathrm{Yb}^{3+} / 2 \% \mathrm{Er}^{3+}$ phosphor has the highest emission intensity, and the intensity of UC luminescence enhanced by

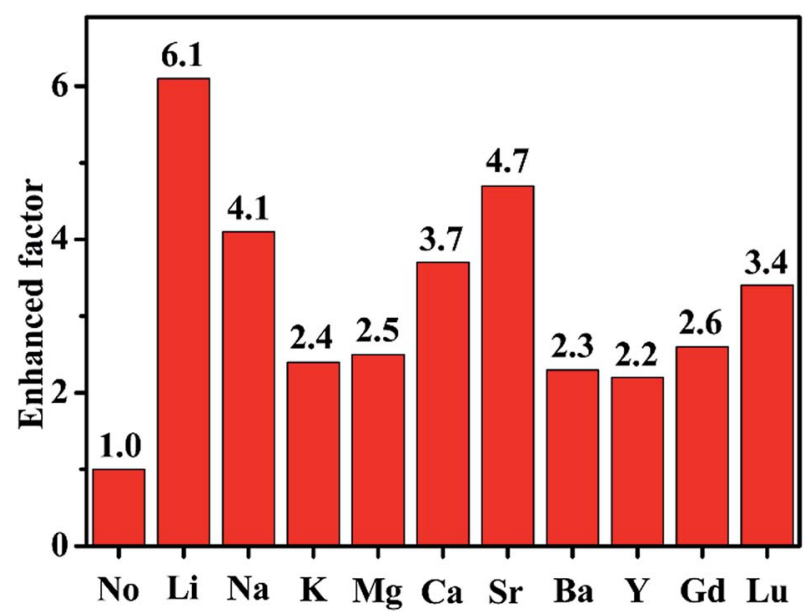

Fig. 6 The enhanced factor of UCL intensity of $\mathrm{ScVO}_{4}: 10 \% \mathrm{Yb}^{3+} / 2 \%$ $\mathrm{Er}^{3+}$ doped with various optical-inert ions $\left(\mathrm{Li}^{+}, \mathrm{Na}^{+}, \mathrm{K}^{+}, \mathrm{Mg}^{2+}, \mathrm{Ca}^{2+}\right.$, $\mathrm{Sr}^{2+}, \mathrm{Ba}^{2+}, \mathrm{Y}^{3+}, \mathrm{Gd}^{3+}$ or $\left.\mathrm{Lu}^{3+}\right)$ 


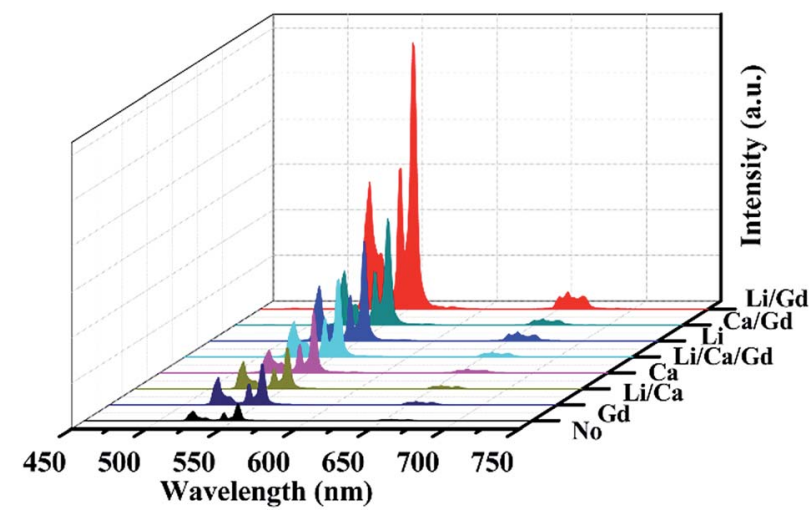

Fig. 7 UC emission spectra of $\mathrm{Li}^{+}, \mathrm{Ca}^{2+}, \mathrm{Gd}^{3+}$ single-, $\mathrm{co}$ - or tri-doped $\mathrm{ScVO}_{4}: 10 \% \mathrm{Yb}^{3+} / 2 \% \mathrm{Er}^{3+}$.

a factor of 15.3 compared to the optical-inert ions free sample, and the codoping of $\mathrm{Ca}^{2+} / \mathrm{Gd}^{3+}$ ions followed. That is to say the combination of $\mathrm{Li}^{+} / \mathrm{Gd}^{3+}$ or $\mathrm{Ca}^{2+} / \mathrm{Gd}^{3+}$ present more excellent UCL intensity than that of corresponding optical-inert ions single doped or free samples. While, the combination of $\mathrm{Li}^{+}$/ $\mathrm{Ca}^{2+} / \mathrm{Gd}^{3+}$ or $\mathrm{Li}^{+} / \mathrm{Ca}^{2+}$ weakened the UCL intensity compared to that of the $\mathrm{Li}^{+}$or $\mathrm{Ca}^{2+}$ single doped samples, respectively.

Fig. 8 shows the emission colors of optical-inert ions doped $\mathrm{ScVO}_{4}: 10 \% \mathrm{Yb}^{3+} / 2 \% \mathrm{Er}^{3+}$ samples under excitation at $980 \mathrm{~nm}$. The apparent color difference in the digital images (collected using a Canon Power Shot G7) also show that optical-inert ions doped $\mathrm{ScVO}_{4}: 10 \% \mathrm{Yb}^{3+} / 2 \% \mathrm{Er}^{3+}$ samples has bright green emission under NIR laser excitation. Furthermore, the green light spot is biggest in the $\mathrm{Li}^{+} / \mathrm{Gd}^{3+}$ codoped system, and smallest in $\mathrm{ScVO}_{4}: 10 \% \mathrm{Yb}^{3+} / 2 \% \mathrm{Er}^{3+}$ samples, which is agree well with the measured spectra results.

\subsection{Reasons for UC emission intensity enhanced by non- optical ions doping}

To reveal the reasons for UC emission intensity enhancing trend in our system as follows: $5 \% \mathrm{Li}^{+}>1 \% \mathrm{Ca}^{2+}>10 \% \mathrm{Gd}^{3+}>$ optical-

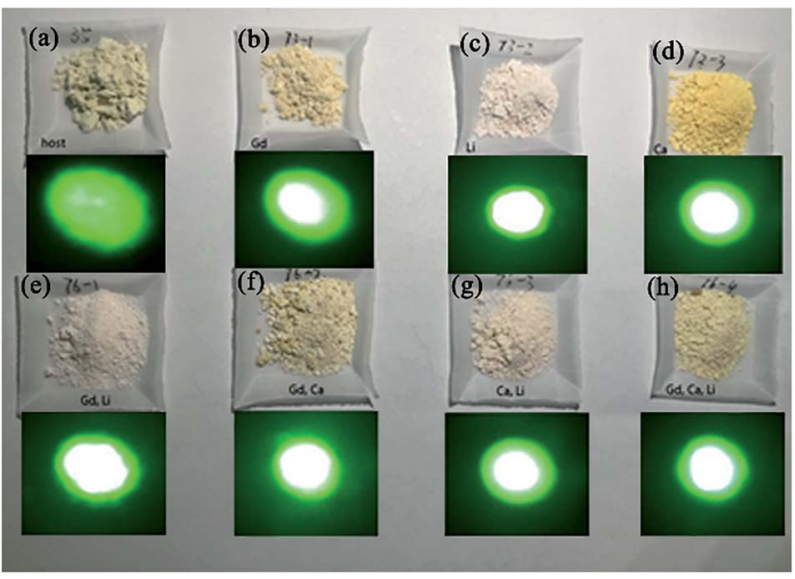

Fig. 8 Emission color of (a) $\mathrm{ScVO}_{4}: 10 \% \mathrm{Yb}^{3+} / 2 \% \mathrm{Er}^{3+}$, (b) $\mathrm{Gd}^{3+}$, (c) $\mathrm{Li}^{+}$, (d) $\mathrm{Ca}^{2+}$, (e) $\mathrm{Li}^{+} / \mathrm{Gd}^{3+}$, (f) $\mathrm{Ca}^{2+} / \mathrm{Gd}^{3+}$, (g) $\mathrm{Li}^{+} / \mathrm{Ca}^{2+}$ and (h) $\mathrm{Li}^{+} / \mathrm{Ca}^{2+} / \mathrm{Gd}^{3+}$ doped $\mathrm{ScVO}_{4}: 10 \% \mathrm{Yb}^{3+} / 2 \% \mathrm{Er}^{3+}$. inert ions free sample, XRD Rietveld refinement, SEM, XPS etc. were employed for the crystal structure analysis and luminescence performance investigation.

Generally, the factors affecting luminescence intensity are various and complex, including its crystal structure, shape, size, phonon modes, etc. ${ }^{\mathbf{1 1 4}}$ In our work, it can be seen above that phase of all prepared samples is the same with the standard pattern of $\mathrm{ScVO}_{4}$ (JCPDS Card, File No. 06-0260), indicating that those optical-inert ions get incorporated into the $\mathrm{ScVO}_{4}$ matrix without phase separation, so the benefit of phase effect on the luminescence augmentation can be excluded. However, doping those optical-inert ions leads to the change of lattice cell. From the enlarged spectra which are dominated by the shifting of main diffraction peaks (220) of tetragonal phase $\mathrm{ScVO}_{4}$ as shown in Fig. 1b and c, we can see that the peak shifts changed as the different optical-inert ions doping. To see how crystal structure quantitatively evolves along with the addition of optical-inert ions $\left(\mathrm{Li}^{+}, \mathrm{Ca}^{2+}\right.$ or $\left.\mathrm{Gd}^{3+}\right)$, these raw data of XRD were analyzed by Rietveld refinement method. ${ }^{46-49}$ Fig. 9 shows the Rietveld analysis pattern of $\mathrm{ScVO}_{4}: \mathrm{Yb}^{3+} / \mathrm{Er}^{3+}$ sample and $\mathrm{Li}^{+}$, $\mathrm{Ca}^{2+}$ or $\mathrm{Gd}^{3+}$ single doped $\mathrm{ScVO}_{4}: \mathrm{Yb}^{3+} / \mathrm{Er}^{3+}$ samples, in which the black crosses, red solid lines, green solid lines, blue lines and magenta bars characterized experimental patterns, calculated patterns, background patterns, differences and Bragg position, respectively. The deviation between the calculated and experimental results are expressed by blue lines, which are shown between the background line and the Bragg reflection line. The refinement results and the main refinement parameters are shown in Table 2 and Table 3. Profile factor $R_{\mathrm{p}}$ lies between $8.24 \%$ to $9.91 \%$, weighted profile factor $R_{\mathrm{wp}}$ is $6.79-$ $8.03 \%$.

These results indicate that the crystal structure data of these samples by Rietveld structural refinement are well matched with experimental data. Due to similarity between refined patterns, we list the refined profile of the sample of $\mathrm{ScVO}_{4}: \mathrm{Yb}^{3+}$ / $\mathrm{Er}^{3+}$ as an example. For $\mathrm{ScVO}_{4}: \mathrm{Yb}^{3+} / \mathrm{Er}^{3+}, R_{\mathrm{p}}=9.89 \%, R_{\mathrm{wp}}=$ $7.97 \%$. The refinement results indicate that $\mathrm{ScVO}_{4}: \mathrm{Yb}^{3+} / \mathrm{Er}^{3+}$
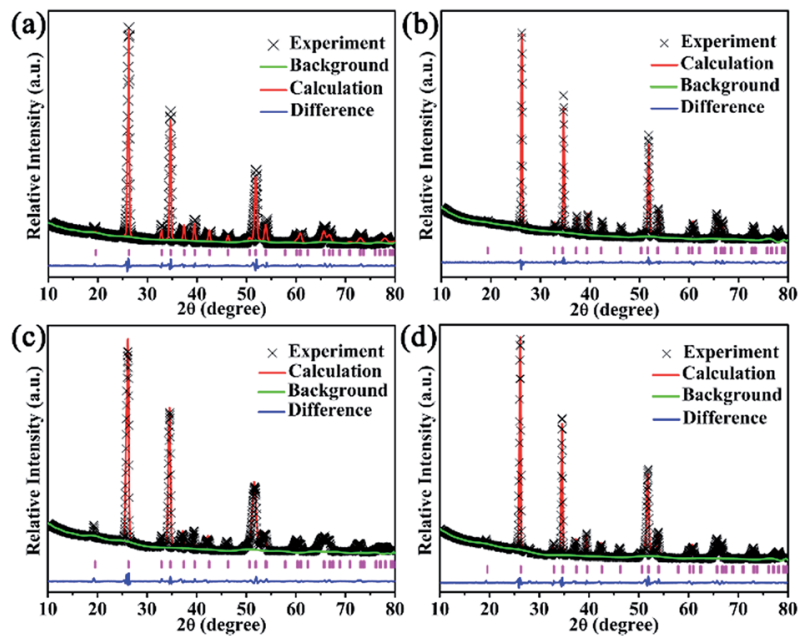

Fig. 9 The Rietveld analysis pattern of (a) $\mathrm{ScVO}_{4}: 10 \% \mathrm{Yb}^{3+} / 2 \% \mathrm{Er}^{3+}$, (b) $\mathrm{Li}^{+}$, (c) $\mathrm{Ca}^{2+}$, (d) $\mathrm{Gd}^{3+}$ doped $\mathrm{ScVO}_{4}: 10 \% \mathrm{Yb}^{3+} / 2 \% \mathrm{Er}^{3+}$. 
Table 2 Crystallographic data of $\mathrm{Li}^{+}, \mathrm{Ca}^{2+}$, or $\mathrm{Gd}^{3+}$ doped $\mathrm{ScVO}_{4}: \mathrm{Yb}^{3+} / \mathrm{Er}^{3+}$ samples derived from Rietveld refinement of X-ray diffraction

\begin{tabular}{lllll}
\hline Bond lengths and angles & No & $\mathrm{Li}^{+}$ & $\mathrm{Ca}^{2+}$ & $\mathrm{Gd}^{3+}$ \\
Crystal system & Tetragonal & Tetragonal & Tetragonal & Tetragonal \\
Space group & $I 4_{1} /$ amd & $I 4_{1} /$ amd & I4 $/$ amd & I4 $/$ amd \\
$Z$ & 4 & 4 & 4 & 4 \\
Cell parameters/ & $a=b=6.8289, c=6.1709$ & $a=b=6.8375, c=6.1705$ & $a=b=6.8454, c=6.1728$ & $a=b=6.8148, c=6.1597$ \\
Cell volume $/ \AA^{3}$ & 287.77 & 288.48 & 289.25 & 286.07 \\
Profile factor $R_{\mathrm{p}}$ & $9.89 \%$ & $8.24 \%$ & $9.91 \%$ & $9.77 \%$ \\
Weighted profile factor $R_{\mathrm{wp}}$ & $7.97 \%$ & $6.79 \%$ & $7.77 \%$ & $8.03 \%$ \\
\hline
\end{tabular}

Table 3 Selected bond lengths and angles of $\mathrm{Li}^{+}, \mathrm{Ca}^{2+}$, or $\mathrm{Gd}^{3+}$ doped $\mathrm{ScVO}_{4}: \mathrm{Yb}^{3+} / \mathrm{Er}^{3+}$ samples based on Rietveld refinement of $\mathrm{X}$-ray diffraction

\begin{tabular}{llll}
\hline $\begin{array}{l}\text { Bond lengths and } \\
\text { angles }\end{array}$ & No & $\mathrm{Li}^{+}$ & $\mathrm{Ca}^{2+}$ \\
Sc1-O1 & $2.377(8) \AA$ & $2.408(4) \AA$ & $2.376(16) \AA$ \\
Sc1-O2 & $2.129(11) \AA$ & $2.116(6) \AA$ & $\mathrm{Gd}^{3+}$ \\
Sc1-O-Sc1 & $112.4(5)^{\circ}$ & $111.83(29)^{\circ}$ & $2.134(21) \AA$ \\
\end{tabular}

and $\mathrm{Li}^{+}, \mathrm{Ca}^{2+}$ or $\mathrm{Gd}^{3+}$ single doped $\mathrm{ScVO}_{4}: \mathrm{Yb}^{3+} / \mathrm{Er}^{3+}$ phosphors belong to tetragonal phase, and its space group is $I 4_{1} /$ amd with $Z=4$. The refined unit cell parameters are $a=b=6.8289 \AA$ А $c=$ $6.1709 \AA$ and cell volume $V=287.77 \AA^{3}$ for $\mathrm{ScVO}_{4}: \mathrm{Yb}^{3+} / \mathrm{Er}^{3+}$ sample. For $\mathrm{Li}^{+}, \mathrm{Ca}^{2+}$ or $\mathrm{Gd}^{3+}$ single doped $\mathrm{ScVO}_{4}: \mathrm{Yb}^{3+} / \mathrm{Er}^{3+}$ samples, the unit cell parameters are $a=b=6.8375 \AA, c=$ $6.1705 \AA$, cell volume $V=288.48 \AA^{3} ; a=b=6.8454 \AA, c=6.1728$ $\AA$, cell volume $V=289.25 \AA^{3}$ and $a=b=6.8148 \AA, c=6.1597 \AA$, cell volume $V=286.07 \AA^{3}$, respectively. Obviously, the trend of increment for the cell volume $V$ as: $\mathrm{Ca}^{2+}>\mathrm{Li}^{+}>$No optical-inert ions $>\mathrm{Gd}^{3+}$. The emergence of the result may be caused by that these optical-inert ions can be doped into the host lattice through the substitution or occupation of the interstitial. As shown in Fig. 10, for tetragonal phase $\mathrm{ScVO}_{4}$, each $\mathrm{Sc}^{3+}$ ion is eight-coordinated by $\mathrm{O}$ atoms. In $10 \% \mathrm{Yb}^{3+} / 2 \% \mathrm{Er}^{3+}$-doped $\mathrm{ScVO}_{4}$ sample, the two kinds of Sc-O bond lengths are 2.377(8) and $2.129(11) \AA$, respectively. The angles of Sc-O-Sc is $112.4(5)^{\circ}$. The corresponding bond lengths and bond angles of $\mathrm{Li}^{+}, \mathrm{Ca}^{2+}$ or $\mathrm{Gd}^{3+}$ single doped $\mathrm{ScVO}_{4}: \mathrm{Yb}^{3+} / \mathrm{Er}^{3+}$ samples are deposited in Table 2. Compared with the $\mathrm{ScVO}_{4}: \mathrm{Yb}^{3+} / \mathrm{Er}^{3+}$ sample, the decreased $\mathrm{Sc}-\mathrm{O}$ average bond length will change the surrounding environment of $\mathrm{Yb}^{3+}$ and $\mathrm{Er}^{3+}$ and break the local crystal field symmetry around the $\mathrm{Er}^{3+}$ ions, leading to a low symmetric site of the $\mathrm{Er}^{3+}$ ions, which can make an enhancement in UC efficiency. It is worthwhile pointing out that Sc-O average bond length of $\mathrm{Li}^{+}$doping sample changed the most, in accordance with the UCL intensity of this sample is the highest.

Besides, it is considered that the larger size and more regular morphology has higher UCL intensity, while it is noticed from the Table 1 that the size are not consistant with the UC luminescence intensity perfectly, thus, the benefit of the crystalline size effect on the luminescence enhancement is not an important factor. Thus, the enhancement mechanisms of optical-inert ions should be searched from other directions.

On one hand, to investigate chemical composition of the material surface, a well-known, extensively used X-ray photon spectroscopy (XPS) technique was used. ${ }^{50-52}$ Fig. 11a and b shows the XPS spectra of $\mathrm{Sc}(2 \mathrm{p}), \mathrm{V} 2 \mathrm{p} 3 / 2$ and $\mathrm{V} 2 \mathrm{p} 1 / 2$ regions (between 455-467 eV) for $\mathrm{ScVO}_{4}: \mathrm{Yb}^{3+} / \mathrm{Er}^{3+}$ sample and $\mathrm{Li}^{+}, \mathrm{Ca}^{2+}$, $\mathrm{Gd}^{3+}$ single doped $\mathrm{ScVO}_{4}: \mathrm{Yb}^{3+} / \mathrm{Er}^{3+}$ samples. These results confirm the +3 oxidation state of $\mathrm{Sc}$ and $\mathrm{V}$ in its +5 oxidation state. ${ }^{51,53}$ Moreover, the XPS spectra of $\mathrm{O} 1 \mathrm{~s}$ are used as a probe
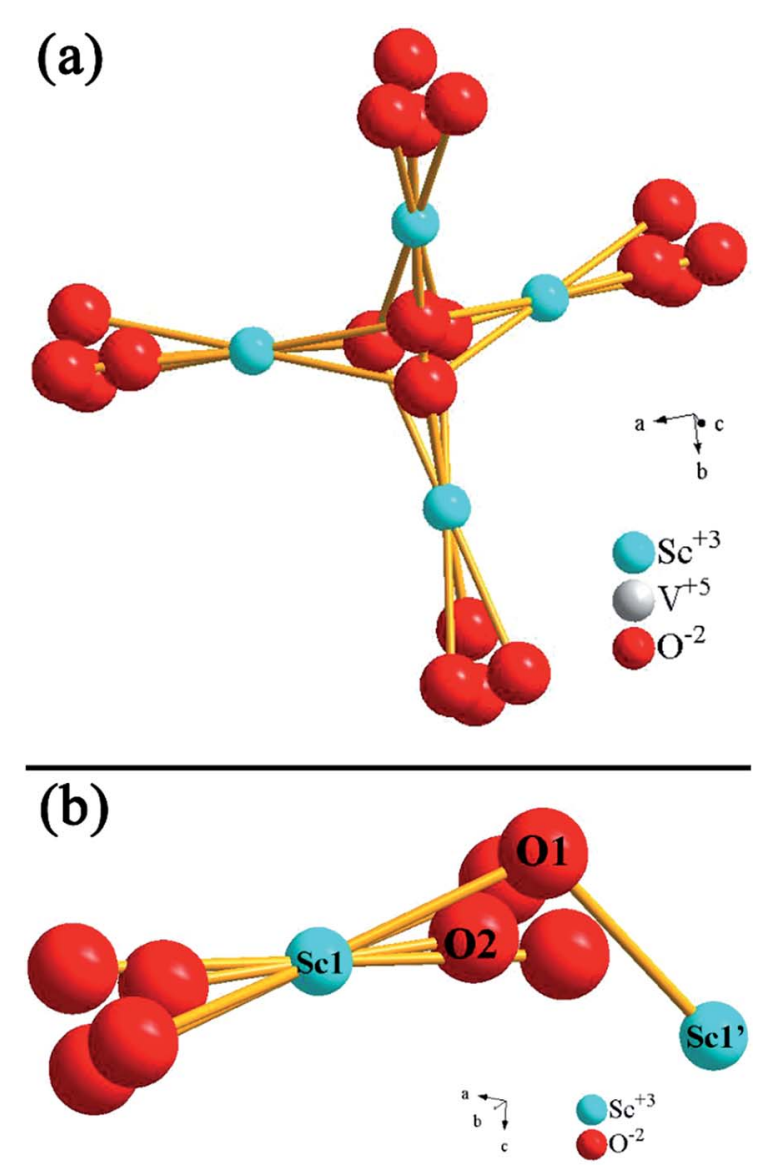

Fig. 10 Crystal structure of the tetragonal phase $\mathrm{ScVO}_{4}$ drawn using the Diamond software. 
(a)
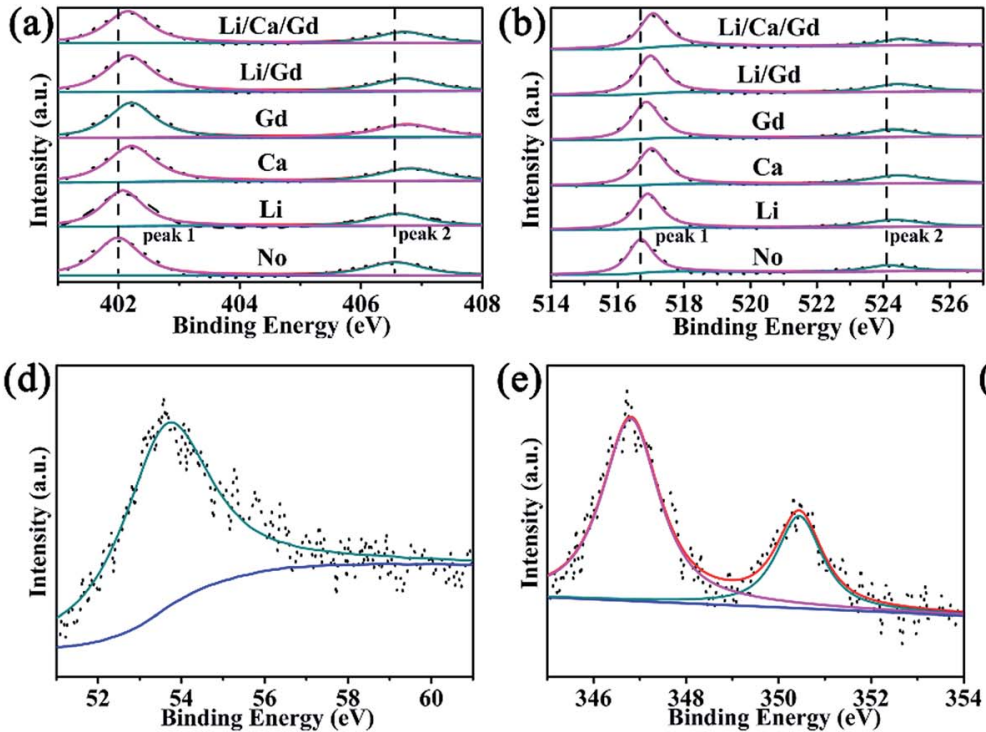

(e)

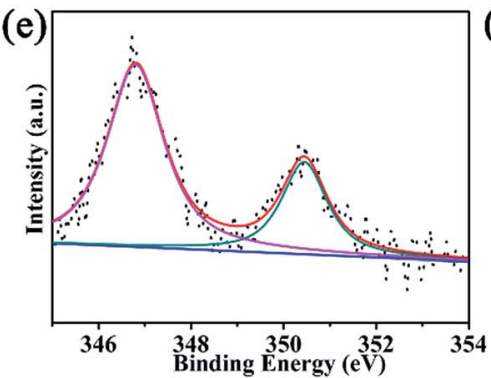

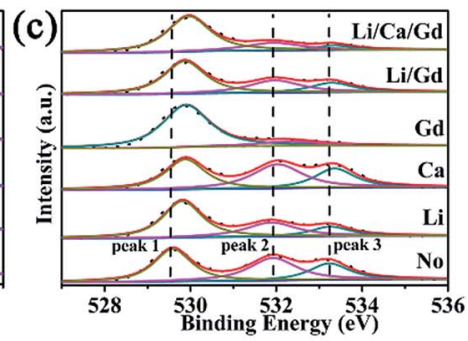

(f)

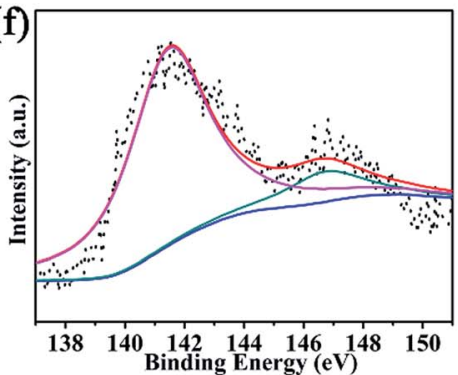

Fig. 11 XPS and their peak fitting curves of (a) Sc 2p, (b) V 2p, (c) O 1s, (d) Li 1s, (e) Ca 2p, and (f) Gd 4d of Gd ${ }^{3+}, \mathrm{Li}^{+}, \mathrm{Ca}^{2+} \mathrm{doped} \mathrm{ScVO}_{4}: 10 \% \mathrm{Yb}^{3+} / 2 \%$ $\mathrm{Er}^{3+}$, respectively.

for investigating the presence of oxygen ion vacancies on the surface of sample. The peaks were de-convoluted using Lorentzian function. In the case of $\mathrm{ScVO}_{4}: \mathrm{Yb}^{3+} / \mathrm{Er}^{3+}$ sample, the two peaks well fitted to $\mathrm{BE} \sim 529.57$ (P1) and $531.97 \mathrm{eV}$ (P2) with FWHM $\sim 1.08$ and $1.32 \mathrm{eV}$, respectively. Upon optical-inert ions doping, all the peaks showed asymmetric behaviour towards higher BE. Moreover, the decrease extent of the P2/P1 ratio of optical-inert ions doped samples is as follows: $1 \% \mathrm{Ca}^{2+}<5 \% \mathrm{Li}^{+}<$ $10 \% \mathrm{Gd}^{3+}$, as shown in Fig. 11c. This is probably because of the creation of oxygen ion vacancies and/or surface defects through the sample surface with introduction of optical-inert ions into the host matrix. It can be concluded from the analysis of XPS spectra that the creation of appropriate amounts of oxygen ion vacancies and/or surface defects through the sample surface with the introduction of optical-inert ions into the host matrix, which are beneficial to the stronger UCL. This is because of a lower or optimal proportion of optical-inert ions incorporation into the host lattice, thus inducing a fast ET from the host to the $\mathrm{Er}^{3+}$ ion. This may create the vacancies that act as the sensitizer, mixing the charge-transfer states. Optical-inert ions addition increased the UCL intensity by increasing the radiative transition probability. However, an increase in the optical-inert ions concentration or type over a certain limit (such as $10 \% \mathrm{Gd}^{3+}$ in this work) generates a significant amount of oxygen ion vacancies in the lattice. Consequently, the crystal lattice collapses, and the luminescence intensity decreases. Therefore, the brightness increases with oxygen ion vacancies concentration to certain extent, if above this point, the luminescence begins to decrease, then quenching behavior appears as a result.

Based on the experiment results described above, in $\mathrm{ScVO}_{4}$ phosphor, it can be concluded that optical-inert ions doping induced change of local symmetry and oxygen vacancy generated should be the main reason that is responsible for UC emission enhancement. In addition, morphology and size of the obtained samples also contributes to the enhanced UC emission. In order to interpret the effects of these optical-inert ions doping on the UCL process, the dependence of emission intensity on the pump power for the red, green emission was measured, in order to better verify the role of the optical-inert ions played in the energy transfer of UC emissions. As a commonly used method, the relationship between integrated emission intensity I and excitation power $P, I_{\mathrm{em}}=P^{n}$ is often used to provide the information of $n$ photons involved in the UC process. ${ }^{14}$ For comparison, the power dependence of S0-S4 samples are shown in Fig. 12. Considering the energy transfer UC process, the population of emissive levels will be greatly influenced by the energy transfer process showing a changeable $n$ value. It is demonstrated whether in $\mathrm{ScVO}_{4}: 10 \% \mathrm{Yb}^{3+} / 2 \% \mathrm{Er}^{3+}$ (S0) or optical-inert ions doped $\mathrm{ScVO}_{4}: 10 \% \mathrm{Yb}^{3+} / 2 \% \mathrm{Er}^{3+}$ (S1-S4),

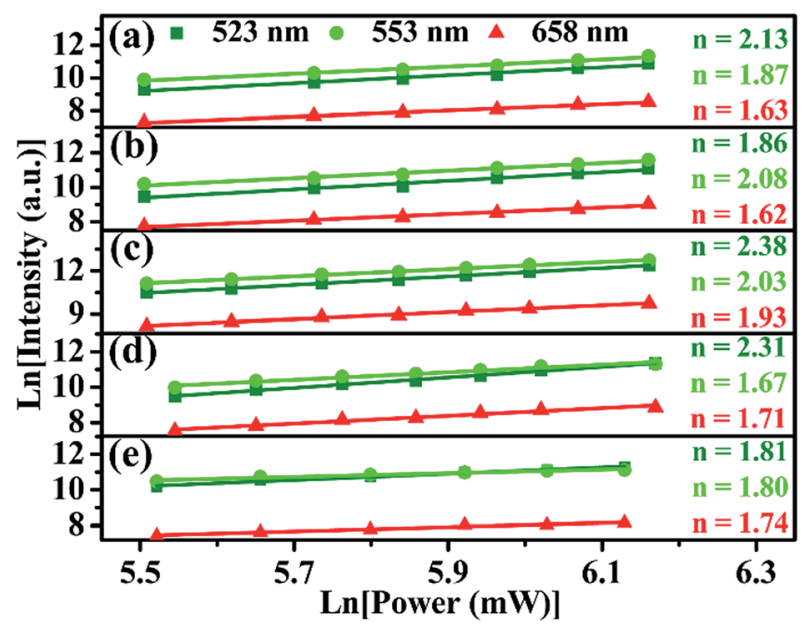

Fig. 12 Pump power dependence of the fluorescent bands centered at $523 \mathrm{~nm}, 554 \mathrm{~nm}$ and $659 \mathrm{~nm}$ in (a) $\mathrm{Gd}^{3+} / \mathrm{Ca}^{2+}$, (b) $\mathrm{Li}^{+}$, (c) $\mathrm{Gd}^{3+}$, (d) $\mathrm{Ca}^{2+}$, (e) without co-doped $\mathrm{ScVO}_{4}: 10 \% \mathrm{Yb}^{3+} / 2 \% \mathrm{Er}^{3+}$. 
the slop value $n$ are all approximate to 2 both for the green and red. As the slope denotes the number of NIR photons absorbed to generate one frequency upconverted photon under unsaturated conditions, the green and red emissions are two-photon processes both in the UCPs doping optical-inert ions or not. The UC mechanism of this system is similar to our previous work. $^{40}$

\subsection{Temperature sensing properties $\mathrm{ScVO}_{4}: 10 \% \mathrm{Yb}^{3+} / 2 \% \mathrm{Er}^{3+}$ and $5 \% \mathrm{Li}^{+} / 10 \% \mathrm{Gd}^{3+}$ codoped $\mathrm{ScVO}_{4}: 10 \% \mathrm{Yb}^{3+} / 2 \% \mathrm{Er}^{3+}$}

It is also interesting to find that $\mathrm{ScVO}_{4}: 10 \% \mathrm{Yb}^{3+} / 2 \% \mathrm{Er}^{3+}$ microparticles have optical-thermal sensing performance. To investigate influences of optical-inert ions on the temperaturesensing behaviour of $\mathrm{ScVO}_{4}: 10 \% \mathrm{Yb}^{3+} / 2 \% \mathrm{Er}^{3+}, 5 \% \mathrm{Li}^{+} / 10 \% \mathrm{Gd}^{3+}$ codoped $\mathrm{ScVO}_{4}: 10 \% \mathrm{Yb}^{3+} / 2 \% \mathrm{Er}^{3+}$ with the highest UC luminescence intensity was chosen as a representative. It is well known that the ${ }^{2} \mathrm{H}_{11 / 2}$ and ${ }^{4} \mathrm{~S}_{3 / 2}$ levels of the $\mathrm{Er}^{3+}$ ion are thermally coupled, leading to the change of the transitions of ${ }^{2} \mathrm{H}_{11 / 2} \rightarrow$ ${ }^{4} \mathrm{I}_{15 / 2}(522 \mathrm{~nm})$ and ${ }^{4} \mathrm{~S}_{3 / 2} \rightarrow{ }^{4} \mathrm{I}_{15 / 2}(554 \mathrm{~nm})$ of $\mathrm{Er}^{3+}$ at different temperatures. ${ }^{54-57}$ According to Boltzmann distribution theory, the emission intensity ratio $(R)$ of the $522 \mathrm{~nm}$ and $554 \mathrm{~nm}$ transitions can be written as follows: ${ }^{43}$

$$
R=\frac{I_{522}}{I_{554}}=B \exp \left(-\frac{\Delta E}{k T}\right)
$$

where $I_{522}$ and $I_{554}$ are the intensities corresponding to the ${ }^{2} \mathrm{H}_{11 / 2} \rightarrow{ }^{4} \mathrm{I}_{15 / 2}(522 \mathrm{~nm})$ and ${ }^{4} \mathrm{~S}_{3 / 2} \rightarrow{ }^{4} \mathrm{I}_{15 / 2}(554 \mathrm{~nm})$ transitions, respectively, $B$ is the pre-exponential constant, $\Delta E$ is the energy gap between the ${ }^{2} \mathrm{H}_{11 / 2}$ and ${ }^{4} \mathrm{~S}_{3 / 2}$ levels, $k$ is Boltzmann's constant and $T$ is absolute temperature. Eqn (1) can be also converted in the form of a linear equation as:

$$
\operatorname{Ln}(R)=-\frac{\Delta E}{k T}+\operatorname{Ln}(B)
$$

The UC emission spectra at various temperatures and curves of the emission intensity ratio $(R)$ versus temperature $(T / K)$ for $\mathrm{ScVO}_{4}: 10 \% \mathrm{Yb}^{3+} / 2 \% \mathrm{Er}^{3+}$ and $\mathrm{ScVO}_{4}: 10 \% \mathrm{Yb}^{3+} / 2 \% \mathrm{Er}^{3+} / 5 \% \mathrm{Li}^{+} /$ $10 \% \mathrm{Gd}^{3+}$ are presented in Fig. 13a and $\mathrm{b}$, respectively. The intensity of the UC emission bands around $522 \mathrm{~nm}$ and $554 \mathrm{~nm}$ seemed to drastically vary with increasing temperature of the sample. The plots of $\operatorname{Ln}(R)$ versus $1 / T$ are exhibited in Fig. 13c and $\mathrm{d}$, the slope $(-\Delta E / k)$ is a very important parameter to judge the optical temperature sensing ability of $\mathrm{Er}^{3+}$ doped materials, and the linear fitting of the experimental data gave slope and intercept equal to $-655.15 \pm 16.22$ and $-511.12 \pm 38.57$ for both of these two samples, respectively. Besides, the sensor sensitivity is another important coefficient of a sensing material. The sensor sensitivity $(S)$ can be defined as

$$
S=\frac{\mathrm{d} R}{\mathrm{~d} T}=R\left(\frac{\Delta E}{k T}\right)=B\left(\frac{\Delta E}{k T^{2}}\right) \exp \left(-\frac{\Delta E}{k T}\right)
$$

Actually, with increasing temperature, the absolute sensitivity for both two samples first increases, then reach a certain temperature it starts decreasing (Fig. 14). It is noteworthy that the sensitivity increases dramatically in the $\mathrm{ScVO}_{4}: 10 \% \mathrm{Yb}^{3+} / 2 \%$
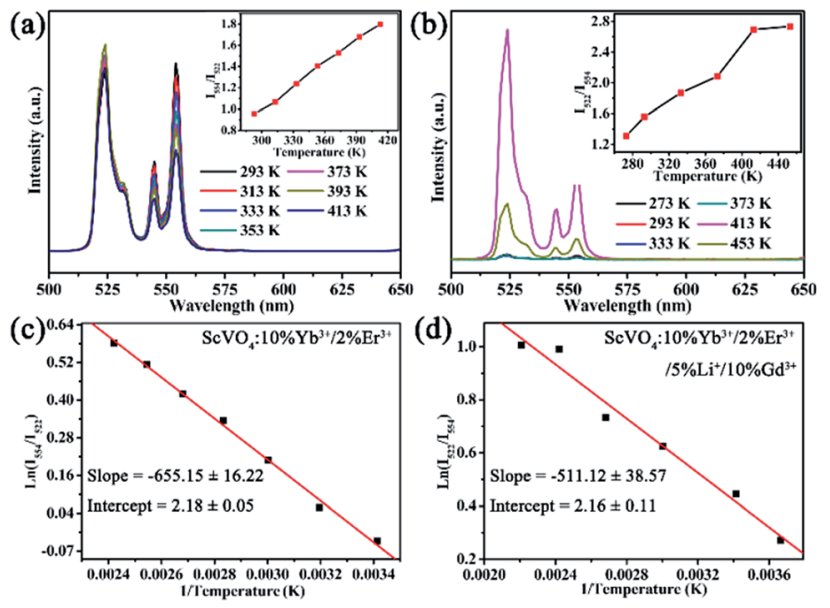

Fig. 13 Green UC emission spectra of $\mathrm{ScVO}_{4}: 10 \% \mathrm{Yb}^{3+} / 2 \% \mathrm{Er}^{3+}(\mathrm{a})$ and $\mathrm{ScVO}_{4}: 10 \% \mathrm{Yb}^{3+} / 2 \% \mathrm{Er}^{3+} / 5 \% \mathrm{Li}^{+} / 10 \% \mathrm{Gd}^{3+}$ (b) phosphors on increasing temperatures and the variation of emission intensity ratio $(R)$ as function of absolute temperature (inset). (c, d) Monolog plots of $R$ as a function of inverse absolute temperature for these two samples, fitted by eqn (2).

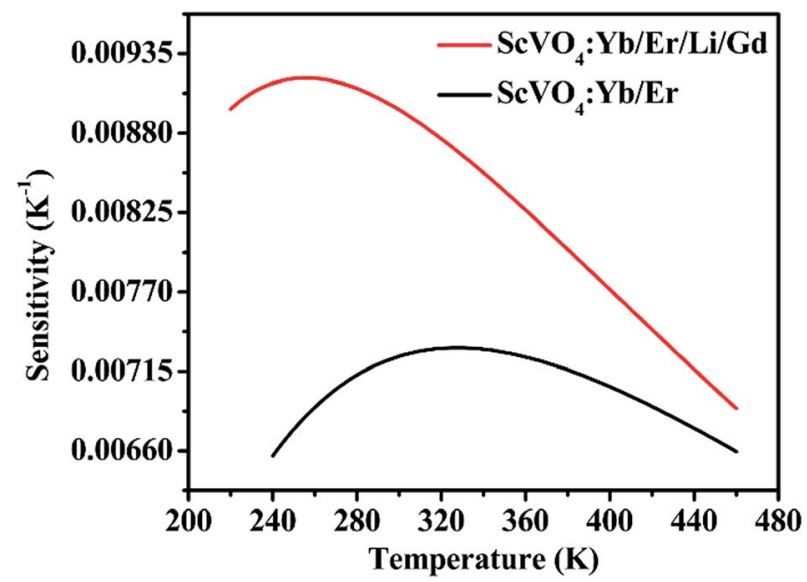

Fig. 14 Relative sensitivity of the as-prepared $\mathrm{ScVO}_{4}: 10 \% \mathrm{Yb}^{3+} / 2 \% \mathrm{Er}^{3+}$ and $5 \% \mathrm{Li}^{+} / 10 \% \mathrm{Gd}^{3+}$ codoped $\mathrm{ScVO}_{4}: 10 \% \mathrm{Yb}^{3+} / 2 \% \mathrm{Er}^{3+}$ samples for optical thermometry as a function of temperature, fitted by eqn (3).

$\mathrm{Er}^{3+} / 5 \% \mathrm{Li}^{+} / 10 \% \mathrm{Gd}^{3+}$ sample compared to the $\mathrm{Li}^{+} / \mathrm{Gd}^{3+}$ free sample. At the temperature of $260 \mathrm{~K}$, the sensitivity of $\mathrm{ScVO}_{4}: 10 \% \mathrm{Yb}^{3+} / 2 \% \mathrm{Er}^{3+} / 5 \% \mathrm{Li}^{+} / 10 \% \mathrm{Gd}^{3+}$ reached its maximum value of about $0.0092 \mathrm{~K}^{-1}$, while the maximum sensitivity of $\mathrm{ScVO}_{4}: 10 \% \mathrm{Yb}^{3+} / 2 \% \mathrm{Er}^{3+}$ only $0.0073 \mathrm{~K}^{-1}$ at $330 \mathrm{~K}$. The results indicated that the multifunctional optical-inert ions $\mathrm{Li}^{+} / \mathrm{Gd}^{3+}$ could be used not only to enhance the temperature sensor sensitivity but also the UCL intensity.

\section{Conclusions}

To sum up, this study reveals that the influences of different optical-inert metal ions including alkali metal, alkaline earth metal as well as inactive $\mathrm{Ln}^{3+}$ ions were discussed by varying the doping content and the combination way. Successful 
incorporation of optical inert ions into $\mathrm{ScVO}_{4}$ lattices was supported by XRD and XPS. Under a $980 \mathrm{~nm}$ laser diode excitation, for optical-inert metal ions single doping system, $5 \% \mathrm{Li}^{+}$is demonstrated as the most effective dopant to enhance the UCL intensity as high as 6.1 times among $\mathrm{Li}^{+} / \mathrm{Na}^{+} / \mathrm{K}^{+} / \mathrm{Mg}^{2+} / \mathrm{Ca}^{2+} / \mathrm{Sr}^{2+} /$ $\mathrm{Ba}^{2+} / \mathrm{Y}^{3+} / \mathrm{Gd}^{3+} / \mathrm{Lu}^{3+}$. For codoping or tridoping optical-inert metal ions system, it is found that $\mathrm{Li}^{+} / \mathrm{Gd}^{3+}$ couple is the most effective codopant, leading to an drastic increase by a factor of 15.3 compared to optical-inert metal ions free sample. In addition, the color coordinates of all samples are located in the green region. The UC luminescence enhancement after codoping optical-inert ions were ascribed to the interaction of a variety of factors, such as larger size, oxygen vacancy, crystal environment distortation. Furthermore, temperature-sensing performance was also investigated using the fluorescence intensity ratio technique. For $\mathrm{ScVO}_{4}: 10 \% \mathrm{Yb}^{3+} / 2 \% \mathrm{Er}^{3+}$, the maximum sensitivity was found to be $0.0073 \mathrm{~K}^{-1}$ at $330 \mathrm{~K}$. Surprisingly, $5 \% \mathrm{Li}^{+} / 10 \% \mathrm{Gd}^{3+}$ codoped $\mathrm{ScVO}_{4}: 10 \% \mathrm{Yb}^{3+} / 2 \% \mathrm{Er}^{3+}$ with the highest UC luminescence intensity was as a temperature sensor with maximum sensitivity of $0.0092 \mathrm{~K}^{-1}$ at $260 \mathrm{~K}$. The investigation results establish the understanding of opticalinert metal ions as dopants for adjusting UCL performance and may be helpful for researchers to develop quick responsive UCL materials. This opens a new window for studying the cooperation of the optically inert ions doping effect on improving UC luminescence and temperature sensitivity properties of $\mathrm{ScVO}_{4}: 10 \% \mathrm{Yb}^{3+} / 2 \% \mathrm{Er}^{3+}$ phosphors.

\section{Conflicts of interest}

There are no conflicts to declare.

\section{Acknowledgements}

The authors gratefully acknowledge China Postdoctoral Science Foundation (2016M592308), Chinese Academy of Sciences (Grants XDA09030203), the NSFH (142300410223), and Student Innovation and Entrepreneur ship Program of Zhengzhou University (SIEP, 2015xjxm180) for their financial support.

\section{References}

1 J. Zhou, Q. Liu, W. Feng, Y. Sun and F. Y. Li, Chem. Rev., 2015, 115, 395-465.

2 H. H. Fang, J. Yang, J. Feng, T. Tamao, S. Hotta and H. B. Sun, Laser Photonics Rev., 2014, 8, 687-715.

3 F. Wang and X. G. Liu, Chem. Soc. Rev., 2009, 38, 976-989.

4 L. L. Han, Y. H. Wang, L. N. Guo, L. Zhao and Y. Tao, Nanoscale, 2014, 6, 5907-5917.

5 H. R. Yang, C. M. Han, X. J. Zhu, Y. Liu, K. Y. Zhang, S. J. Liu, Q. Zhao, F. Y. Li and W. Huang, Adv. Funct. Mater., 2016, 26, 1945-1953.

6 Y. Liu, Q. Q. Su, M. Chen, Y. Dong, Y. B. Shi, W. Feng, Z. Y. Wu and F. Y. Li, Adv. Mater., 2016, 28, 6625-6630.

7 W. B. Hu, X. M. Lu, R. C. Jiang, Q. L. Fan, H. Zhao, W. X. Deng, L. Zhang, L. Huang and W. Huang, Chem. Commun., 2013, 49, 9012-9014.
8 S. H. C. Askes, W. Pomp, S. L. Hopkins, A. Kros, S. Wu, T. Schmidt and S. Bonnet, Small, 2016, 12, 5579-5590.

9 G. Y. Chen, H. L. Qiu, P. N. Prasad and X. Y. Chen, Chem. Rev., 2014, 114, 5161-5214.

10 H. Dong, S. R. Du, X. Y. Zheng, G. M. Lyu, L. D. Sun, L. D. Li, P. Z. Zhang, C. Zhang and C. H. Yan, Chem. Rev., 2015, 115, 10725-10815.

11 W. Yu, W. Xu, H. W. Song and S. Zhang, Dalton Trans., 2014, 43, 6139-6147.

12 Y. Tian, B. N. Tian, C. E. Cui, P. Huang, L. Wang and B. J. Chen, RSC Adv., 2015, 5, 14123-14128.

13 Y. Y. Tian, Y. Tian, P. Huang, L. Wang, Q. F. Shi and C. E. Cui, Chem. Eng. J., 2016, 297, 26-34.

14 F. Auzel, Chem. Rev., 2004, 104, 139-173.

15 J. Y. Liao, Z. W. Yang, H. J. Wu, D. Y. Yan, J. B. Qiu, Z. G. Song, Y. Yang, D. C. Zhou and Z. Y. Yin, J. Mater. Chem. C, 2013, 1, 6541-6546.

16 B. Shao, Z. W. Yang, Y. D. Wang, J. Li, J. Z. Yang, J. B. Qiu and Z. G. Song, ACS Appl. Mater. Interfaces, 2015, 7, 25211-25218. 17 G. Y. Chen, H. C. Liu, H. J. Liang, G. Somesfalean and Z. G. Zhang, J. Phys. Chem. C, 2008, 112, 12030-12036.

18 Q. Cheng, J. H. Sui and W. Cai, Nanoscale, 2012, 4, 779-784. 19 H. Lin, D. K. Xu, D. D. Teng, S. H. Yang and Y. L. Zhang, New J. Chem., 2015, 39, 2565-2572.

20 M. K. Mahata, T. Koppe, T. Mondal, C. Brüsewitz, K. Kumar, V. K. Rai, H. Hofsäss and U. Vetter, Phys. Chem. Chem. Phys., 2015, 17, 20741-20753.

21 Q. M. Huang, J. C. Yu, E. Ma and K. M. Lin, J. Phys. Chem. C, 2010, 114, 4719-4724.

22 J. Tang, L. Chen, J. Li, Z. Wang, J. H. Zhang, J. G. Zhang, Y. S. Luo and X. J. Wang, Nanoscale, 2015, 7, 14752-14759.

23 Q. Sun, H. Zhao, X. Q. Chen, F. P. Wang, W. Cai and Z. H. Jiang, Mater. Chem. Phys., 2010, 123, 806-810.

24 Y. F. Bai, Y. X. Wang, G. Y. Peng, K. Yang, X. R. Zhang and Y. L. Song, J. Alloys Compd., 2009, 478, 676-678.

25 H. N. Luitel, R. Chand, H. Hamajima, Y. R. Gaihre, T. Shingae, T. Yanagita and T. J. Watari, J. Mater. Chem. B, 2016, 4, 6192-6199.

26 L. N. Guo, Y. H. Wang, Y. Z. Wang, J. Zhang, P. Y. Dong and W. Zeng, Nanoscale, 2013, 5, 2491-2504.

27 L. Lei, D. Q. Chen, J. Xu, R. Zhang and Y. S. Wang, Chem.Asian J., 2014, 9, 728-733.

28 V. Singh, V. K. Rai, I. J. Lee, I. Ledoux-Rak, K. Al-Shamery, J. Nordmann and M. Haase, Appl. Phys. B, 2012, 106, 223228.

29 F. Wang, Y. Han, C. S. Lim, Y. H. Lu, J. Wang, J. Xu, H. Y. Chen, C. Zhang, M. H. Hong and X. G. Liu, nature, 2010, 463, 1061.

30 G. T. Xiang, J. H. Zhang, Z. D. Hao, X. Zhang, G. H. Pan, Y. S. Luo and H. F. Zhao, CrystEngComm, 2015, 17, 31033109.

31 H. J. Liang, Y. D. Zheng, G. Y. Chen, L. Wu, Z. G. Zhang and W. W. Cao, J. Alloys Compd., 2011, 509, 409-413.

32 D. G. Li, W. P. Qin, P. Zhang, L. L. Wang, M. Lan and P. B. Shi, Opt. Mater. Express, 2017, 7, 329-340.

33 L. Mukhopadhyay, V. K. Rai, R. Bokolia and K. Sreenivas, J. Lumin., 2017, 187, 368-377. 
34 Y. F. Bai, Y. X. Wang, K. Yang, X. R. Zhang, Y. L. Song and C. H. Wang, Opt. Commun., 2008, 281, 5448-5452.

35 Q. Cheng, J. H. Sui and W. Cai, Nanoscale, 2012, 4, 779-784. 36 V. Mahalingam, R. Naccache, F. Vetrone and J. A. Capobianco, Opt. Express, 2010, 20, 111-119.

37 J. H. Chung, S. Y. Lee, K. B. Shim, S. Y. Kweon, S. C. Ur and J. H. Ryu, Appl. Phys. A, 2012, 108, 369-373.

38 X. W. Wang, X. Zhang, Y. B. Wang, H. Y. Li, J. Xi, T. Wei, Q. W. Huang, X. J. Xie, L. Huang and W. Huang, Dalton Trans., 2017, 46, 8968-8974.

39 S. S. Du, D. Y. Wang, Q. P. Qiang, X. L. Ma, Z. B. Tang and Y. H. Wang, J. Mater. Chem. C, 2016, 4, 7148-7155.

40 C. X. Liang, L. N. Guo, P. Li, T. S. Li, P. L. Chen, M. H. Liu and Y. J. Wu, J. Alloys Compd., 2017, 715, 37-42.

41 S. S. Zhou, K. M. Deng, X. T. Wei, G. C. Jiang, C. K. Duan, Y. H. Chen and M. Yin, Opt. Commun., 2013, 291, 138-142.

42 F. Huang, Y. Gao, J. C. Zhou, J. Xu and Y. S. Wang, J. Alloys Compd., 2015, 639, 325-329.

43 M. Xu, D. Q. Chen, P. Huang, Z. Y. Wan, Y. Zhou and Z. G. Ji, J. Mater. Chem. C, 2016, 4, 6516-6524.

44 I. Hyppänen, N. Perälä, R. Arppe, M. Schäferling and T. Soukka, ChemPhysChem, 2017, 18, 692-701.

45 A. J. Huang, Z. W. Yang, C. Y. Yu, J. B. Qiu and Z. G. Song, J. Am. Ceram. Soc., 2017, 100, 4994-4998.

46 I. Sosnowska, W. Schäfer, W. Kockelmann, K. H. Andersen and I. O. Troyanchuk, Appl. Phys. A, 2002, 74(Suppl. 1), S1040-S1042.
47 T. Katsufuji, M. Masaki, A. Machida, M. Moritomo, K. Kato, E. Nishibori, M. Takata, M. Sakata, K. Ohoyama, K. Kitazawa and H. Takagi, Phys. Rev. B, 2002, 66, 134434.

48 F. W. Kang, L. J. Li, J. Han, D. Y. Lei and M. Y. Peng, J. Mater. Chem. C, 2017, 5, 390-398.

49 J. G. Cheng, P. L. Li, Z. J. Wang, Y. S. Sun, Q. Y. Bai, Z. L. Li, M. M. Tian, C. Wang and Z. P. Yang, J. Mater. Chem. C, 2017, 5, 127-133.

50 B. J. Tan, K. J. Klabunde and P. M. A. Sherwood, J. Am. Chem. Soc., 1991, 113, 855-861.

51 G. Silversmit, D. Depla, H. Poelman, G. B. Marin and R. D. Gryse, J. Electron Spectrosc. Relat. Phenom., 2004, 135, 167-175.

52 M. C. Biesinger, L. W. M. Lau, A. R. Gerson and R. S. C. Smart, Appl. Surf. Sci., 2010, 257, 887-898.

53 B. P. Singh, A. K. Parchur, R. S. Ningthoujam, P. V. Ramakrishna, S. Singh, P. Singh, S. B. Rai and R. Maalej, Phys. Chem. Chem. Phys., 2014, 16, 22665-22676.

54 G. Paez and M. Strojnik, Appl. Opt., 2003, 42, 3251-3258.

55 S. F. Leon-Luis, U. R. Rodriguez-Mendoza, I. R. Martin, E. Lalla and V. Lavin, Sens. Actuators, B, 2013, 176, 11671175.

56 J. S. Liao, L. L. Nie, Q. Wang, S. J. Liu, H. R. Wen and J. P. Wu, RSC Adv., 2016, 6, 35152-35159.

57 S. B. Liu, S. F. Liu, M. Zhou, X. Y. Ye, D. J. Hou and W. X. You, RSC Adv., 2017, 7, 36935-36948. 